\title{
The Role of Data Providers as Information Intermediaries
}

\author{
Nic Schaub*
}

\begin{abstract}
This study investigates whether financial data providers serve as information intermediaries in capital markets. To this end, I examine whether the timeliness of earnings information disseminated by First Call (Thomson Reuters) affects the market's reaction to earnings announcements. I document that the immediate price and volume response is weaker and the post-earnings-announcement drift stronger for earnings news disseminated with a delay by First Call. To mitigate endogeneity concerns, I study the market reaction on the day of the delayed dissemination and show that a significant part of the stronger drift is clustered around this day.
\end{abstract}

\section{Introduction}

The understanding of how information is created and transmitted in financial markets is of crucial importance. Existing research shows that analysts, institutional investors, and the media serve as important information intermediaries. ${ }^{1}$ An information intermediary provides information that is useful to investors,

*Schaub (corresponding author), nic.schaub@unisg.ch, University of St. Gallen. I am indebted to David Oesch for his support. I am also grateful to Martin Brown, Janet Gao, Tobin Hanspal, Jarrad Harford (the editor), Alexander Hillert, Harrison Hong, Moritz Osnabruegge, Joel Peress, K. Ramesh, Otto Randl, Stefan Ruenzi, Markus Schmid, Eric So (the referee), Michael Ungeheuer, Felix von Meyerinck, Rex Wang, conference participants at the 2014 European Finance Association annual meeting in Lugano, the 2016 German Finance Association annual meeting in Bonn, the 2017 Swiss Society for Financial Market Research annual conference in Zurich, and seminar participants at the University of Mannheim, Rotterdam School of Management, Bocconi University, and the University of St. Gallen for helpful comments. Part of this research was undertaken while I was a visiting researcher at UCLA Anderson School of Management. Financial support from the Swiss National Science Foundation (SNF) is gratefully acknowledged.

${ }^{1}$ For instance, Brennan, Jegadeesh, and Swaminathan (1993) document that information is more rapidly incorporated into stock prices if firms are followed by many sell-side analysts, suggesting that analysts serve as information intermediaries in financial markets. El-Gazzar (1998) provides evidence that the higher the institutional holdings in a stock, the lower the price reaction to earnings releases, which is consistent with institutional investors providing information through trading. Moreover, Bushee, Core, Guay, and Hamm (2010) show that greater press coverage reduces bid-ask spreads and increases market depth, suggesting that the press shapes the information environment in capital markets. 
either because it has not been publicly released or because it has not been widely disseminated (Bushee et al. (2010)). In this study, I investigate the role of major financial data providers in shaping the information environment and influencing the trading behavior of investors. To the best of my knowledge, I am the first to analyze whether the processing and distribution of news by financial data suppliers matter for the capital market's reaction to that news. ${ }^{2}$

Specifically, I investigate whether the timeliness of earnings information disseminated by the data provider First Call, which belongs to Thomson Reuters, affects the stock market's reaction to earnings announcements. First Call provides an ideal setting for such an investigation for two reasons: First, it is a leading provider of earnings information in financial markets, for both actuals and forecasts. ${ }^{3}$ Second, First Call reports not only the date on which a firm makes an earnings announcement but also the date on which the earnings news is entered into the First Call system, which allows me to examine the timeliness of earnings information dissemination. First Call might be an important information intermediary in capital markets because it is extensively used by institutional investors as well as by a large number of media outlets (Thomson Reuters/Thomson Financial (2002)). First Call might also matter because it validates earnings data and adjusts actuals to make them comparable to forecasts. Thereby, First Call plays a crucial role in the determination of earnings surprises. Through these activities, it has the potential to shape the information environment in financial markets and affect investors' reaction to earnings releases. However, if First Call does not reach a broader group of investors than other information intermediaries or if it does not add new essential information, the timeliness of information dissemination by First Call does not affect stock markets. Thus, exploring the role of data providers as potential information intermediaries remains an empirical task.

I examine the stock market's reaction to more than 100,000 quarterly earnings announcements disseminated by First Call from 1995 to 2011. I show that First Call distributes approximately $20 \%$ of announced earnings with a delay of at least 1 trading day. Delays mainly occur as the data undergo numerous manual and automated validations and quality checks, and because First Call adjusts actuals to make them comparable to consensus forecasts (Thomson Reuters/Thomson Financial (2006), (2008), (2013)). To the extent that data suppliers matter for the market reaction to earnings announcements, I expect to see a lower initial price reaction and a higher post-earnings-announcement drift for earnings news disseminated with a delay by First Call. Consistent with this conjecture, I find that the 2-day abnormal announcement stock price response to earnings releases is approximately $20 \%$ weaker and the subsequent drift over the 3 months following

${ }^{2} \mathrm{~A}$ crash of Bloomberg terminals in Apr. 2015 that led to major disruptions for traders around the globe provides anecdotal evidence that large data providers can affect trading activity (see, e.g., J. Cox and A. Trivedi, "Bloomberg Terminals Go Down Globally," Wall Street Journal (Apr. 17, 2015), https:/www.wsj.com/articles/bloomberg-terminals-go-down-globally-1429262782).

${ }^{3}$ The three major providers of earnings information used to be First Call, Institutional Brokers' Estimate System (IBES), and Zacks (see, e.g., R. D. Hershey, Jr., "Investing IT: A Flourishing Industry, Predicting What Is and Isn't Flourishing," New York Times (May 17, 1998), https://www.nytimes.com/1998/05/17/business/investing-it-a-flourishing-industry-predictingwhat-is-and-isn-t-flourishing.html). Thomson Reuters (previously Thomson Financial) took over both First Call and IBES in the early 2000s. 
the earnings announcement is approximately $60 \%$ stronger for delayed disseminations compared to immediate disseminations. I control for earnings, firm, and market characteristics that might influence the timeliness and at the same time the stock market response to earnings announcements, as well as for firm and calendar fixed effects. The inclusion of firm fixed effects implies that the effect is estimated by comparing earnings announcements disseminated with a delay to earnings announcements disseminated immediately for the same firm.

Nevertheless, the associations I document using my baseline research design do not necessarily reflect a causal effect of delayed disseminations on stock prices but might still be due to alternative explanations such as reverse causality or omitted variables. To address potential endogeneity concerns, I investigate abnormal returns around the day of the delayed dissemination by First Call. I conjecture that more information is incorporated into prices when First Call disseminates the delayed information than on nondissemination days in the post-earningsannouncement window. As I control for potentially confounding events around the day of the delayed dissemination, this investigation allows me to plausibly isolate the effect of the dissemination by First Call on the stock market reaction to earnings news. I document a significant abnormal stock price reaction in the direction of the earnings surprise upon delayed disseminations of earnings information by First Call, suggesting that a disproportionate part of the stronger drift documented for delayed distributions is clustered around the day of the delayed dissemination.

I then investigate how the timeliness of information dissemination by major data suppliers affects trading activity around earnings news. If the documented price reaction is driven by fewer investors knowing about the earnings announcement or having the relevant earnings data to trade upon it, I also expect to see lower abnormal announcement trading volume for earnings news disseminated with a delay. Consistent with expectations, I show that the 2-day average abnormal announcement trading volume is approximately $10 \%$ lower if First Call disseminates the earnings information with a delay compared to immediate disseminations. I rerun my identification test and document that there is a significant abnormal volume reaction around the day of the delayed dissemination by First Call, which again poses a particular challenge to non-data-provider explanations.

In an additional test, I examine whether the timeliness of information dissemination by data providers also affects market liquidity around earnings releases. Consistent with the idea that delayed disseminations by First Call lead to greater information asymmetry among market participants and thereby reduce market liquidity (compared to immediate disseminations), I show that delayed disseminations are associated with greater abnormal bid-ask spreads and lower abnormal depths during earnings announcement windows.

I then replicate my analysis using IBES rather than First Call data. IBES is another data provider of earnings information. I focus on earnings announcements that are unique to the IBES database and find results similar to (albeit weaker than) those for First Call, suggesting that investors also rely on IBES as a processor and distributor of earnings information.

In my final test to corroborate my findings, I analyze whether the timeliness of information dissemination matters not only for earnings but also for sell-side analyst recommendations. First Call disseminates both earnings information and 
analyst recommendations. I document a weaker immediate stock price reaction and a stronger postannouncement drift for recommendations disseminated with a delay similar to the effect I document for earnings. Moreover, I again find a significant price reaction on the day of the delayed dissemination of analyst recommendations, which lends further support to the idea that investors trade on the information distributed by First Call.

This study contributes to two strands of the literature. First, it adds to the growing literature exploring the role of information intermediaries in financial markets. Early work shows that analysts and institutional investors shape the information environment in capital markets (e.g., Brennan et al. (1993), Brennan and Subrahmanyam (1995), El-Gazzar (1998), and Piotroski and Roulstone (2004)). More recently, various studies report that the media plays a crucial role in the distribution of information across investors (e.g., Huberman and Regev (2001), Bushee et al. (2010), Engelberg and Parsons (2011), Li, Ramesh, and Shen (2011), Blankespoor, Miller, and White (2014), Peress (2014), Rogers, Skinner, and Zechman (2016), and Twedt (2016)). ${ }^{4}$ While existing research documents the role played by analysts, institutional investors, and the media, much less is known about the economic importance of financial data providers. Thus, my contribution is to investigate the role of financial data providers as information intermediaries. D'Souza, Ramesh, and Shen (2010) show that Standard \& Poor's Compustat database distributes firms' final quarterly accounting data with an average time lag of 18 weekdays and that institutional investors relying on corporate accounting information are the key drivers of the timeliness of information dissemination. My focus is not on the dissemination speed of accounting information in periodic SEC reports but on the distribution of earnings news following earnings announcements and on the market's reaction to that news. Thereby, I provide direct evidence on the role financial data providers play in the processing and transmission of information in financial markets.

Second, this study contributes to the large body of research that examines the market response to earnings announcements. Ball and Brown (1968) are among the first to note that stock prices continue to drift in the direction of earnings surprises for several months after the earnings are announced. Bernard and Thomas (1989) reject risk as an explanation for the post-earnings-announcement drift and hypothesize that it could be caused by the speed of investors' response to new information. More recently, a number of studies provide empirical evidence that when investors' attention to new information is limited, earnings news diffuses slowly (e.g., DellaVigna and Pollet (2009), Hirshleifer, Lim, and Teoh (2009), Hou, Peng, and Xiong (2009), deHaan, Shevlin, and Thornock (2015), and Frederickson and Zolotoy (2016)). Because investors have a limited amount of time and cognitive resources to process news, they tend to rely on only a few sources for their information. This study adds to this literature by showing that many investors choose to acquire information through major financial data

\footnotetext{
${ }^{4}$ Financial data providers are fundamentally different from the press and newswires in that they cover the market as a whole and process financial data. In contrast, the press focuses on specific events and creates new information through journalism activities (see, e.g., Bushee et al. (2010)). Moreover, newswires are hired by managers to transmit selected press releases to media outlets and thus focus on the pure rebroadcasting of information (see, e.g., Twedt (2016)).
} 
providers, and the speed with which these data suppliers process and distribute information offers an alternative explanation for the initial underreaction to earnings news and the post-earnings-announcement drift.

The study proceeds as follows: In the next section, I describe the role of financial data providers as information intermediaries in greater detail. I also outline how I measure the timeliness of information dissemination and the stock price reaction to earnings announcements. In Section III, I examine the relation between the timeliness of earnings information distribution by First Call and the capital market's reaction to earnings announcements. In Section IV, I present a test to mitigate endogeneity concerns. In Section V, I conduct a diverse set of robustness tests to corroborate my findings. Section VI concludes.

\section{Data and Variables}

\section{A. Data Providers}

Only a handful of large players provide data on actual earnings and earnings forecasts: First Call, IBES, and Zacks. First Call and IBES were both taken over by Thomson Reuters (previously Thomson Financial) in the early 2000s. These data suppliers perform various tasks: In a first step, they collect analysts' earnings forecasts and reported actuals, and double-check earnings information for reasonableness. They then determine consensus forecasts, adjust actuals to make them comparable to consensus forecasts, and calculate earnings surprises. Finally, they distribute all the information in packed form on their own platforms and through platforms of third-party distributors such as Bloomberg. ${ }^{5}$ Almost $100 \%$ of fund managers of actively managed equity funds in the U.S. are reported to rely on some form of First Call information (Thomson Reuters/Thomson Financial (2002)). Anecdotal evidence also suggests that hedge funds implement automated trading strategies using First Call and IBES data. ${ }^{6}$ In addition, First Call data are used by hundreds of media outlets and thus reach a very broad range of investors. ${ }^{7}$

\section{B. Delayed Disseminations of Earnings News}

I start the construction of my sample by collecting quarterly earnings announcements as reported by First Call. As the aim of my study is to investigate the effects of different timings of earnings information dissemination, correct earnings announcement dates are crucial. Thus, I cross-check the announcement dates in First Call with those in Compustat and keep observations only when the dates in the two databases are identical. DellaVigna and Pollet (2009) find that the accuracy of earnings announcement dates in Compustat is "almost perfect" (p. 715) after Dec. 1994. Hence, my sample period begins in Jan. 1995. Thomson Reuters stopped updating the database available to researchers in June 2011. Therefore,

\footnotetext{
${ }^{5}$ Appendix A shows how earnings information is reported on the Thomson ONE platform.

${ }^{6}$ See, for example, “Thomson's Tack on Research,” Securities Industry News (Jan. 16, 2006).

${ }^{7}$ Newspapers such as the Financial Times, New York Times, USA Today, Wall Street Journal, and Washington Post as well as cable television news providers such as CNBC and CNN are said to rely on First Call data (Thomson Reuters/Thomson Financial (2002)). In addition, Internet platforms such as Yahoo! Finance also distribute First Call information.
} 
my data set ends in June 2011. I obtain an initial sample of 254,972 earnings announcements.

My main independent variable of interest is a dummy indicating whether the news of a particular earnings announcement is disseminated with a delay by First Call. First Call reports the date on which a firm makes an earnings announcement (the announcement date) as well as the date on which the earnings news is entered into the First Call system (the activation date). I calculate the difference in trading days between the activation date and the announcement date. I then create an indicator variable that equals 1 if First Call disseminates the earnings news with a delay of at least 1 trading day (i.e., if the time lag between the activation date and the announcement date is positive), and 0 if First Call disseminates the earnings news immediately on the day of the earnings announcement (i.e., if the time lag is 0). ${ }^{8}$ If the earnings announcement or the activation in First Call takes place outside of trading hours (i.e., after 4 PM), I allocate the observation to the next trading day to correctly determine immediate and delayed disseminations of earnings news. I delete 2,292 observations with missing activation dates (i.e., observations for which I cannot calculate the time lag between the activation date and the announcement date). I also eliminate 331 observations with negative time lags between the activation date and the announcement date, as an inclusion of an earnings announcement in the database before its publication is not meaningful. Moreover, I exclude 6,616 observations with a time lag of more than 3 months (61 trading days) to eliminate outliers. Table IA1 in the Internet Appendix (available at www.jfqa.org) describes the sample selection process in greater detail. My final sample contains 102,759 earnings announcements.

What might be the reasons for the delayed dissemination of earnings news? First Call strives to "report actual earnings as soon as they are released into the market place" (Thomson Reuters/Thomson Financial (2006), p. 6). Nevertheless, delays occur because data providers perform a large number of manual and automated validations and quality checks upon receipt of the data to ensure that big deviations from past actuals and forecasts are reasonable. ${ }^{9}$ Delays also occur because financial data providers adjust actuals so that they are comparable to the majority of forecasts ("majority rule"; Thomson Reuters/Thomson Financial (2006), (2008), (2013))..$^{10}$ As soon as the integrity of the data has been ensured and adjustments have been made, actuals are entered into the system. Appendix B

\footnotetext{
${ }^{8}$ In my robustness tests, I rerun my analysis with a delayed dissemination dummy variable that equals 1 for time lags larger than 1 trading day, and 0 otherwise. Results remain qualitatively unchanged.

${ }^{9}$ Incoming data undergo more than 7,700 validations and 150 manual and automated quality control checks before being disseminated (Thomson Reuters/Thomson Financial (2008)).

${ }^{10}$ Thomson Reuters says the following about these adjustments: "When a company reports their earnings, the data is evaluated by a Market Specialist to determine if any extraordinary or nonextraordinary items (charges or gains) have been recorded by the company during the period. If no items have been recorded during the period the reported value is entered. If one or more items have been recorded during the period, actuals will be entered based upon the estimates' majority basis at the time of reporting. The Market Specialist will still review each item in relation to the estimate submissions and how similar items have been treated in past periods." (Thomson Reuters/Thomson Financial (2013)).
} 
provides an example of how First Call adjusts its actuals and how this causes delays in the distribution process. ${ }^{11}$

Table 1 provides descriptive statistics on the earnings announcements in my final sample. The number of observations substantially increases, from approximately 2,000 announcements in 1995 to more than 7,000 observations in 1999. From 1999 on, the number remains relatively stable, between 6,000 and 8,000. The lower number of announcements at the beginning of the investigation period is mainly due to a higher number of mismatches between the announcement date in First Call and the announcement date in Compustat. I keep only observations for which the dates in the two databases match. The mean time lag between the activation date in First Call and the announcement date is more than 1 trading day in 1995. It fluctuates between 0.5 and 1 trading day between 1996 and 2009 (except for 1999, where it drops below 0.5), and decreases to less than 0.5 in 2010 and 2011. The fraction of immediate disseminations increases from

\section{TABLE 1}

\section{Descriptive Statistics}

Table 1 presents the distribution of earnings announcements in my sample. The time lag is the difference in trading days between the activation date and the announcement date in First Call. The announcement date refers to the date on which the earnings announcement is made. The activation date refers to the date on which the information is entered into the First Call database. I eliminate observations with missing time lags, observations with negative time lags, and observations with time lags that exceed 61 trading days.

Time Lag between Activation Date and Announcement Date

\begin{tabular}{|c|c|c|c|c|c|c|c|c|c|c|c|c|}
\hline Year & $N$ & Mean & 0 & $\%$ of $N$ & 1 & $\%$ of $N$ & $2-5$ & $\%$ of $N$ & $6-10$ & $\%$ of $N$ & $11-61$ & $\%$ of $N$ \\
\hline 1995 & 1,808 & 1.187 & 897 & $49.6 \%$ & 772 & $42.7 \%$ & 86 & $4.8 \%$ & 15 & $0.8 \%$ & 38 & $2.1 \%$ \\
\hline 1996 & 2,673 & 0.906 & 1,453 & $54.4 \%$ & 1,046 & $39.1 \%$ & 120 & $4.5 \%$ & 9 & $0.3 \%$ & 45 & $1.7 \%$ \\
\hline 1997 & 2,966 & 0.873 & 1,528 & $51.5 \%$ & 1,099 & $37.1 \%$ & 300 & $10.1 \%$ & 13 & $0.4 \%$ & 26 & $0.9 \%$ \\
\hline 1998 & 5,912 & 0.577 & 4,746 & $80.3 \%$ & 979 & $16.6 \%$ & 92 & $1.6 \%$ & 26 & $0.4 \%$ & 69 & $1.2 \%$ \\
\hline 1999 & 7,090 & 0.295 & 6,531 & $92.1 \%$ & 410 & $5.8 \%$ & 69 & $1.0 \%$ & 42 & $0.6 \%$ & 38 & $0.5 \%$ \\
\hline 2000 & 6,801 & 0.650 & 6,144 & $90.3 \%$ & 352 & $5.2 \%$ & 141 & $2.1 \%$ & 49 & $0.7 \%$ & 115 & $1.7 \%$ \\
\hline 2001 & 6,858 & 0.745 & 6,061 & $88.4 \%$ & 390 & $5.7 \%$ & 227 & $3.3 \%$ & 55 & $0.8 \%$ & 125 & $1.8 \%$ \\
\hline 2002 & 6,550 & 0.631 & 5,447 & $83.2 \%$ & 715 & $10.9 \%$ & 243 & $3.7 \%$ & 48 & $0.7 \%$ & 97 & $1.5 \%$ \\
\hline 2003 & 6,503 & 0.620 & 5,218 & $80.2 \%$ & 813 & $12.5 \%$ & 346 & $5.3 \%$ & 52 & $0.8 \%$ & 74 & $1.1 \%$ \\
\hline 2004 & 6,764 & 0.536 & 5,341 & $79.0 \%$ & 879 & $13.0 \%$ & 421 & $6.2 \%$ & 80 & $1.2 \%$ & 43 & $0.6 \%$ \\
\hline 2005 & 7,242 & 0.662 & 5,522 & $76.2 \%$ & 1,032 & $14.3 \%$ & 506 & $7.0 \%$ & 108 & $1.5 \%$ & 74 & $1.0 \%$ \\
\hline 2006 & 7,509 & 0.648 & 5,737 & $76.4 \%$ & 889 & $11.8 \%$ & 720 & $9.6 \%$ & 110 & $1.5 \%$ & 53 & $0.7 \%$ \\
\hline 2007 & 7,557 & 0.503 & 5,863 & $77.6 \%$ & 900 & $11.9 \%$ & 735 & $9.7 \%$ & 38 & $0.5 \%$ & 21 & $0.3 \%$ \\
\hline 2008 & 7,806 & 0.812 & 5,311 & $68.0 \%$ & 1,051 & $13.5 \%$ & 1,301 & $16.7 \%$ & 100 & $1.3 \%$ & 43 & $0.6 \%$ \\
\hline 2009 & 7,644 & 0.604 & 5,997 & $78.5 \%$ & 757 & $9.9 \%$ & 739 & $9.7 \%$ & 103 & $1.3 \%$ & 48 & $0.6 \%$ \\
\hline 2010 & 7,447 & 0.157 & 7,241 & $97.2 \%$ & 74 & $1.0 \%$ & 85 & $1.1 \%$ & 20 & $0.3 \%$ & 27 & $0.4 \%$ \\
\hline 2011 & 3,629 & 0.097 & 3,565 & $98.2 \%$ & 21 & $0.6 \%$ & 26 & $0.7 \%$ & 4 & $0.1 \%$ & 13 & $0.4 \%$ \\
\hline Total & 102,759 & 0.583 & 82,602 & $80.4 \%$ & 12,179 & $11.9 \%$ & 6,157 & $6.0 \%$ & 872 & $0.8 \%$ & 949 & $0.9 \%$ \\
\hline
\end{tabular}

\footnotetext{
${ }^{11}$ Data providers typically collect announced earnings from newswires, press releases, company Web sites, or public filings (Thomson Reuters/Thomson Financial (2006), (2013)). Thus, delayed disseminations could also be due to delayed information distribution by newswires or companies. To address this concern I search newswire articles and press releases available on LexisNexis and analyze when newswires and companies disseminate earnings news. I draw two random samples of 100 earnings announcements each: one for immediate disseminations by data providers and the other for delayed disseminations. I retain the earliest reported time stamp in LexisNexis. For immediate disseminations by First Call, newswires or companies always disseminate the earnings news immediately (i.e., on the day of the earnings announcement), except for one observation for which the First Call date precedes the LexisNexis date. For delayed disseminations, the First Call announcement date equals the date provided by newswires and press releases in $98 \%$ of all cases. In one case, the First Call date precedes the LexisNexis date and for one observation the First Call date follows the LexisNexis date. Hence, delayed disseminations by First Call do not appear to be driven by delayed distributions of the information by newswires or companies.
} 
approximately 50\% in 1995 to more than $90 \%$ in 1999. From 2000 to 2009, it remains relatively stable, between $70 \%$ and $90 \%$. In 2010 and 2011, the percentage of immediate disseminations jumps to $97.2 \%$ and $98.2 \%$, respectively. The higher fraction of immediate disseminations in 2010 and 2011 is due to a change in Thomson Reuters' dissemination practice in Sept. 2009 (Thomson Reuters/Thomson Financial (2013)). Before Sept. 2009, First Call waited until the majority of contributing analysts had issued updated reports. It then adjusted actuals according to the majority basis and distributed the information thereafter. From Sept. 2009 on, First Call immediately distributes most of the earnings information on the earnings announcement day and adjusts it later if necessary, based on the treatment of actuals by the majority of analysts. Over the entire investigation period, $80.4 \%$ of announced earnings are disseminated immediately by First Call and $19.6 \%$ are distributed with a delay. Within 1 week (5 trading days), $98.2 \%$ of earnings are entered into the First Call system and $99.1 \%$ are disseminated within 2 weeks (10 trading days).

\section{Abnormal Returns, Earnings Surprises, and Other Control Variables}

The main dependent variables of interest are the immediate and the delayed stock price response to earnings announcement. I follow previous research and define cumulative abnormal returns (CARs) around the announcement date and over the post-earnings-announcement window as the difference between the buy-andhold return of the respective stock and that of a size and book-to-market matching portfolio (e.g., Hirshleifer et al. (2009), Chi and Shanthikumar (2017)). I obtain stock return data from the Center for Research in Security Prices (CRSP). Only stocks classified as ordinary shares (CRSP share code 10 or 11) are considered. Each stock is matched with 1 of $25(5 \times 5)$ size and book-to-market portfolios at the end of June based on the market capitalization at the end of June and the book equity of the last fiscal year-end in the prior calendar year divided by the market capitalization at the end of December of the prior year. ${ }^{12}$ I follow the convention in the literature and calculate CARs over a 2-day announcement window and a 60-day postannouncement window to capture the immediate and delayed price reactions to earnings news: ${ }^{13}$

$$
\begin{aligned}
\operatorname{CAR}[0,+1]_{i q} & =\prod_{t=0}^{t=1}\left(1+R_{i t}\right)-\prod_{t=0}^{t=1}\left(1+R_{p t}\right), \\
\mathrm{CAR}[+2,+61]_{i q} & =\prod_{t=2}^{t=61}\left(1+R_{i t}\right)-\prod_{t=2}^{t=61}\left(1+R_{p t}\right),
\end{aligned}
$$

where $R_{i t}$ is the daily return of firm $i$ on day $t$ and $R_{p t}$ is the daily return of the matching size and book-to-market portfolio $p$ on day $t$. The earnings announcement of firm $i$ for quarter $q$ takes place on day $t=0$. I winsorize CARs at the $1 \%$ and $99 \%$ levels to ensure that my findings are not driven by outliers.

\footnotetext{
${ }^{12}$ Kenneth French generously provides size and book-to-market breakpoints to form the 25 size and book-to-market portfolios as well as the daily returns of the 25 size and book-to-market portfolios on his Web site: http://mba.tuck.dartmouth.edu/pages/faculty/ken.french/data_library.html

${ }^{13}$ In my robustness tests, I examine the price reaction to earnings releases over alternative announcement and postannouncement windows. This does not materially change my findings.
} 
As control variables in my empirical tests, I use characteristics found to be significantly related to the stock market response to earnings announcements in previous literature (e.g., Bernard and Thomas (1989), Hirshleifer et al. (2009)). I calculate standardized unexpected earnings (SUE) as the difference between the announced earnings and the median consensus forecast scaled by the stock price at the end of the previous calendar quarter:

$$
\mathrm{SUE}_{i q}=\frac{A_{i q}-F_{i q}}{P_{i q}},
$$

where $A_{i q}$ is the announced earnings of firm $i$ for quarter $q, F_{i q}$ is the most recent median consensus forecast for firm $i$ and quarter $q$, and $P_{i q}$ is the stock price of firm $i$ at the end of the most recent calendar quarter. To exclude stale forecasts, I consider only consensus estimates for which at least one analyst issued or reviewed the forecast in the 60 calendar days before the earnings announcement. I delete observations when announced earnings or consensus forecasts are greater than the stock price at the end of the most recent calendar quarter and when the stock price is less than US $\$ 1$ to minimize possible data errors (e.g., Hirshleifer et al. (2009), deHaan et al. (2015)). In addition, I winsorize the earnings surprise measure at the $1 \%$ and $99 \%$ levels to eliminate outliers.

I include a large number of additional control variables in my analyses. I create a dummy variable that equals 1 for earnings announcements for which nonzero extraordinary items and discontinued operations have been recorded by the company. A company's market capitalization is computed at the end of June of each year. The book-to-market ratio is also calculated at the end of June of each year by dividing the book value of equity for the last fiscal year-end in the previous calendar year by the market value of equity at the end of December of the previous calendar year. I construct the percentage of shares held by institutional investors at the end of the most recent calendar quarter from the Thomson Reuters Institutional Holdings (13F) database. The share turnover is defined as average monthly share trading volume divided by the average number of shares outstanding over a 1 -year period ending at the end of the most recent calendar quarter. I determine the number of analysts that form the most recent consensus estimate. Moreover, I take the standard deviation of earnings forecasts that form the most recent consensus forecast and scale it by the absolute value of the mean consensus forecast to capture the dispersion in analyst opinions. Earnings volatility is the standard deviation of the deviations of quarterly earnings from the previous year's quarterly earnings over the past 4 years. I calculate earnings persistence as the first-order autocorrelation coefficient of quarterly earnings over the past 4 years. I compute the reporting lag as the difference between the announcement date and the end of the corresponding fiscal quarter. Finally, I calculate the total number of earnings announcements on each day. I winsorize the book-to-market ratio, share turnover, dispersion in analyst forecasts, earnings volatility, and reporting lag at the $99 \%$ level to eliminate outliers. Appendix $\mathrm{C}$ provides detailed descriptions of all control variables used throughout the study. 


\section{Empirical Analysis: Delayed Dissemination of Earnings News and the Capital Market's Reaction}

\section{A. Univariate Comparisons}

To test for an association between the timeliness of information dissemination by data providers and the capital market's reaction to earnings news, I compare the immediate and delayed stock price responses to earnings announcements for the group of earnings announcements disseminated with a delay and the group of announcements disseminated immediately in a univariate setting. To do so, every calendar quarter, I perform a 2-way independent sort of earnings announcements and split stocks into $20(10 \times 2)$ groups based on the earnings surprise decile and based on whether the information on the earnings announcement is disseminated with a delay or immediately by First Call. For every group, I calculate average 2-day announcement CARs and average 60-day postannouncement CARs. I also calculate the interdecile spread in announcement CARs and post-earningsannouncement CARs between the decile with the most positive earnings surprises (SUE_DECILE $=10$ ) and the decile with the most negative earnings surprises (SUE_DECILE = 1) separately for delayed and immediate disseminations.

I report the results of univariate comparisons of announcement returns in Panel A of Table 2. If market participants make their trading decisions dependent on First Call data, I expect the announcement reaction to be less sensitive to earnings news if First Call disseminates earnings information with a delay. Consistent with this conjecture, I find that the initial stock price response to earnings announcements disseminated with a delay is weaker than the initial response to announcements disseminated immediately. Abnormal return differences between delayed and immediate disseminations are highly statistically significant at the $1 \%$ level for more extreme deciles and either weakly significant or not significant for intermediate deciles. The interdecile spread in announcement CARs amounts to $5.18 \%$ for delayed disseminations, and $6.70 \%$ for immediate disseminations. The difference between the two interdecile spreads is $1.52 \%$ and highly statistically significant $(t$-statistic $=5.68)$.

Panel B of Table 2 shows univariate comparisons of post-earningsannouncement CARs. I expect the post-earnings-announcement drift to be more pronounced if First Call disseminates the earnings information in the postearnings-announcement window. Consistently, I find that the post-earningsannouncement drift of earnings news disseminated with a delay tends to be stronger than the drift of earnings news disseminated immediately. However, only the return difference for the most positive earnings surprises is statistically significant. The interdecile spread in post-earnings-announcement CARs is $4.88 \%$ for delayed disseminations and $2.20 \%$ for immediate disseminations. The difference between the two spreads amounts to $2.68 \%$ and is statistically significant at the $1 \%$ level. Taken together, I find that the immediate stock price response is significantly weaker and the delayed response is significantly stronger for delayed disseminations compared to immediate distributions.

Results are graphically illustrated in Figure 1. I plot the interdecile CAR spreads between the most positive earnings news (SUE_DECILE = 10) and the most negative earnings news (SUE_DECILE $=1$ ) over the entire event and 
TABLE 2

\section{Univariate Comparisons of Earnings Announcements Disseminated with a Delay and Earnings Announcements Disseminated Immediately}

Table 2 presents average 2-day announcement cumulative abnormal returns (CARs) of quarterly earnings announcements (Panel A), average 60-day post-earnings-announcement CARs (Panel B), and average values of earnings, firm, and market characteristics (Panel C) for the group of earnings announcements disseminated with a delay by First Call (DELAYED) and the group of announcements disseminated immediately (IMMEDIATE). CARs are calculated as the difference between the buy-and-hold return of the respective stock and that of a size and book-to-market matching portfolio. An earnings announcement is classified as delayed if First Call disseminates the earnings news with a delay of at least 1 trading day (i.e., if the time lag between the activation date and the announcement date is positive) and it is classified as immediately disseminated if First Call disseminates the earnings news on the day of the earnings announcement (i.e., if the time lag is 0). Earnings announcements are sorted into SUE_DECILE every calendar quarter based on the earnings surprise. Appendix $\mathrm{C}$ provides detailed descriptions of earnings, firm, and market characteristics. Means of the subgroups are tested for equality using a standard $t$-test. ${ }^{* \star}$ and ${ }^{* \star *}$ indicate significance at the $5 \%$ and $1 \%$ levels, respectively.

$\underline{\text { Panel A. Announcement Returns }}$

$\operatorname{CAR}[0,+1](\%)$

\begin{tabular}{|c|c|c|c|c|c|c|}
\hline & Mean & DELAYED & IMMEDIATE & Difference & $t$-Value & $N$ \\
\hline SUE_DECILE $=1$ & -3.397 & -2.923 & -3.648 & 0.725 & $4.02^{\star \star \star}$ & 10,312 \\
\hline SUE_DECILE $=2$ & -2.332 & -2.044 & -2.413 & 0.369 & $2.17^{\star \star}$ & 10,275 \\
\hline SUE_DECILE $=3$ & -1.450 & -1.291 & -1.481 & 0.190 & 1.06 & 10,289 \\
\hline SUE_DECILE $=4$ & -0.873 & -1.026 & -0.847 & -0.179 & -0.92 & 10,263 \\
\hline SUE_DECILE $=5$ & -0.038 & -0.494 & 0.031 & -0.525 & $-2.79^{\star \star \star}$ & 10,257 \\
\hline SUE_DECILE $=6$ & 0.861 & 0.531 & 0.914 & -0.383 & $-2.03^{\star \star}$ & 10,286 \\
\hline SUE_DECILE $=7$ & 1.425 & 1.242 & 1.459 & -0.218 & -1.16 & 10,284 \\
\hline SUE_DECILE $=8$ & 1.922 & 1.311 & 2.054 & -0.743 & $-4.06^{\star \star \star}$ & 10,268 \\
\hline SUE_DECILE $=9$ & 2.266 & 1.631 & 2.434 & -0.802 & $-4.31^{\star \star \star}$ & 10,278 \\
\hline SUE_DECILE $=10$ & 2.830 & 2.253 & 3.050 & -0.797 & $-4.02^{\star \star \star}$ & 10,247 \\
\hline $\begin{array}{l}\text { Difference } 10-1 \\
t \text {-value }\end{array}$ & $\begin{array}{c}6.228 \\
50.47^{* \star \star}\end{array}$ & $\begin{array}{c}5.176 \\
23.36^{\star \star *}\end{array}$ & $\begin{array}{c}6.697 \\
44.94^{\star \star *}\end{array}$ & $\begin{array}{l}-1.521 \\
-5.68^{* \star \star}\end{array}$ & & \\
\hline
\end{tabular}

Panel B. Post-Earnings-Announcement Drift

$\mathrm{CAR}[+2,+61](\%)$

\begin{tabular}{|c|c|c|c|c|c|c|}
\hline & Mean & DELAYED & IMMEDIATE & Difference & $t$-Value & $N$ \\
\hline SUE_DECILE $=1$ & -1.437 & -2.020 & -1.135 & -0.886 & -1.63 & 10,102 \\
\hline SUE_DECILE $=2$ & -0.231 & -0.189 & -0.243 & 0.054 & 0.11 & 10,133 \\
\hline SUE_DECILE $=3$ & -0.174 & -0.474 & -0.116 & -0.358 & -0.72 & 10,189 \\
\hline SUE_DECILE $=4$ & 0.359 & -0.181 & 0.450 & -0.630 & -1.18 & 10,197 \\
\hline SUE_DECILE $=5$ & 0.164 & 0.081 & 0.176 & -0.096 & -0.18 & 10,186 \\
\hline SUE_DECILE $=6$ & -0.018 & 0.440 & -0.090 & 0.530 & 1.09 & 10,205 \\
\hline SUE_DECILE $=7$ & -0.001 & 0.235 & -0.044 & 0.279 & 0.56 & 10,199 \\
\hline SUE_DECILE $=8$ & 0.431 & 0.545 & 0.407 & 0.138 & 0.28 & 10,163 \\
\hline SUE_DECILE $=9$ & 0.985 & 1.438 & 0.867 & 0.571 & 1.10 & 10,165 \\
\hline SUE_DECILE $=10$ & 1.560 & 2.864 & 1.068 & 1.796 & $3.13^{\star \star \star}$ & 10,115 \\
\hline Difference 10-1 & 2.997 & 4.884 & 2.203 & 2.681 & & \\
\hline$t$-value & $8.23^{\star \star \star}$ & $7.18^{\star \star \star}$ & $5.10^{\star \star \star}$ & $3.39^{\star \star \star}$ & & \\
\hline
\end{tabular}

Panel C. Earnings, Firm, and Market Characteristics

\begin{tabular}{|c|c|c|c|c|c|c|}
\hline & Mean & DELAYED & IMMEDIATE & Difference & $t$-Value & $N$ \\
\hline SUE & -0.001 & -0.003 & 0.000 & -0.003 & $-28.67^{\star \star \star}$ & 102,759 \\
\hline ABS_SUE & 0.005 & 0.008 & 0.004 & 0.004 & $43.98^{\star \star \star}$ & 102,759 \\
\hline EXTRA_ITEMS & 0.167 & 0.192 & 0.161 & 0.031 & $10.49^{\star \star \star}$ & 102,759 \\
\hline MARKET_CAP & $5,532.922$ & $2,704.186$ & $6,223.205$ & $-3,519.019$ & $-21.68^{\star \star \star}$ & 102,759 \\
\hline $\mathrm{BM}$ & 0.524 & 0.536 & 0.522 & 0.015 & $4.38^{\star \star \star}$ & 102,759 \\
\hline INSTITUTIONAL & 0.565 & 0.540 & 0.571 & -0.030 & $-12.44^{\star \star \star}$ & 102,759 \\
\hline SHARE_TURNOVER & 0.190 & 0.193 & 0.189 & 0.004 & $2.77^{\star \star \star}$ & 101,678 \\
\hline ANALYSTS & 7.589 & 6.206 & 7.927 & -1.721 & $-38.29^{\star \star \star}$ & 102,759 \\
\hline DISPERSION & 0.173 & 0.241 & 0.157 & 0.085 & $28.71^{\star \star \star}$ & 92,463 \\
\hline EPS_VOLATILITY & 0.222 & 0.267 & 0.212 & 0.055 & $17.55^{\star \star \star}$ & 88,078 \\
\hline EPS_PERSISTENCE & 0.431 & 0.423 & 0.433 & -0.010 & $-3.03^{\star \star \star}$ & 88,061 \\
\hline REPORTING_LAG & 28.974 & 30.754 & 28.539 & 2.215 & $24.94^{\star \star \star}$ & 102,712 \\
\hline ANNOUNCEMENTS & 227.865 & 232.425 & 226.752 & 5.673 & $5.50^{\star \star \star}$ & 102,759 \\
\hline
\end{tabular}

postevent window separately for delayed and immediate disseminations. The weaker announcement effect of delayed disseminations is reflected in the dashed line starting on a lower level than the solid line. As the information not immediately distributed gradually diffuses into the market within the first days after the 


\section{FIGURE 1}

\section{CARs over the Entire Announcement and Postannouncement Window}

Figure 1 shows average interdecile cumulative abnormal return (CAR) spreads between the decile with the most positive earnings surprises (SUE_DECILE $=10$ ) and the decile with the most negative earnings surprises (SUE_DECILE $=1$ ) over the entire event and postevent window for the group of earnings announcements disseminated with a delay by First Call (DELAYED) and the group of announcements disseminated immediately (IMMEDIATE). CARs are calculated as the difference between the buy-and-hold return of the respective stock and that of a size and book-to-market matching portfolio. An earnings announcement is classified as delayed if First Call disseminates the earnings news with a delay of at least 1 trading day (i.e, if the time lag between the activation date and the announcement date is positive), and it is classified as immediately disseminated if First Call disseminates the earnings news on the day of the earnings announcement (i.e., if the time lag is 0 ).

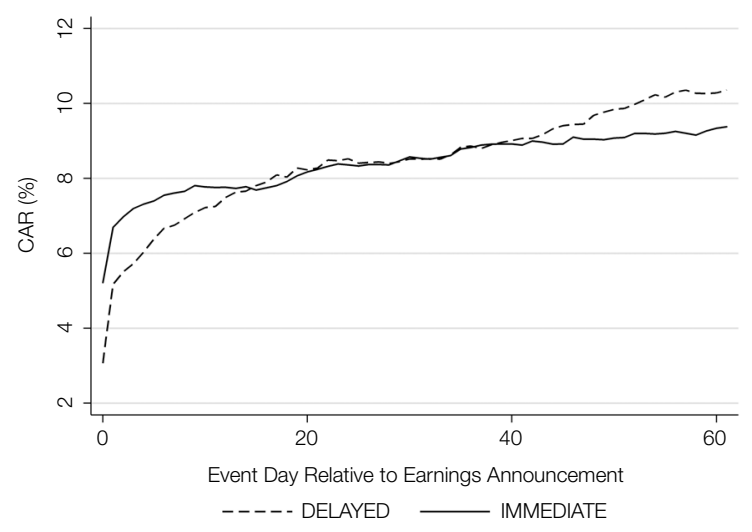

earnings announcements, CARs of delayed disseminations catch up with CARs of immediate disseminations and the dashed line crosses the solid line after 15 trading days, leading to a higher post-earnings-announcement drift for delayed disseminations. The difference in CARs between delayed and immediate disseminations amounts to $0.98 \%$ after 3 months. However, this difference is not statistically significant $(t$-statistic $=1.15)$, which is consistent with the overall information content of the earnings news being similar for the two groups.

Panel C of Table 2 reports results of univariate comparisons of the control variables. A number of these results are consistent with financial data providers' practice of double-checking actuals for reasonableness and adjusting them according to the majority rule. I find that delayed disseminations are associated with more negative earnings surprises and more extreme earnings surprises compared to immediate distributions, which is most likely due to First Call validating that big deviations from forecasts are meaningful. Moreover, the fraction of earnings announcements with nonzero extraordinary items and discontinued operations is significantly higher among delayed disseminations. This is driven by First Call's practice of evaluating whether extraordinary items have been recorded by the company and including or excluding these items based on the treatment by the majority basis. I also document that the dispersion in analyst opinions is higher among delayed disseminations. A dispersed group of analysts makes it more difficult for First Call to determine the majority basis, leading to delays in the distribution of earnings news. I find that past earnings are more volatile and less persistent among delayed disseminations. This is in line with data providers' practice of double-checking whether deviations from past 
actuals are meaningful. Moreover, I document that delays are more common on days when a higher number of announcements are made by other firms. This result is consistent with data providers' having limited capacities and performing some validations and quality checks by hand rather than by machine. In addition, I show that higher institutional ownership is associated with increased timeliness. This is in line with D'Souza et al. (2010) who report that Compustat speeds up its collection efforts for stocks held by institutional owners because institutional investors are the key commercial subscribers to Compustat.

\section{B. Multivariate Analysis}

Next, I investigate the relation between the timeliness of earnings information dissemination by data providers and the capital market's reaction to earnings news in a multivariate setting, which allows the inclusion of control variables as well as fixed effects. I run panel regressions with the 2-day announcement CARs and the 60-day postannouncement CARs as dependent variables. A dummy variable that equals 1 if First Call disseminates the earnings news with a delay, and 0 otherwise, the earnings surprise decile, and an interaction term of the delayed dissemination dummy and the earnings surprise decile are used as the main independent variables. In addition, all earnings, firm, and market characteristics, individually and interacted with the earnings surprise decile, are included in the regression as additional control variables.

$$
\begin{aligned}
\mathrm{CAR}_{i q}= & \alpha+\beta_{1} \mathrm{DELAYED}_{i q}+\beta_{2} \mathrm{SUE} \_D E C I L E_{i q} \\
& +\beta_{3} \mathrm{DELAYED}_{i q} \times \mathrm{SUE} \mathrm{DECILE}_{i q} \\
& +\sum_{k=1}^{n} \gamma_{k} \mathrm{CONTROL}_{i q k} \\
& +\sum_{k=1}^{n} \delta_{k}\left(\mathrm{CONTROL}_{i q k} \times \mathrm{SUE} \_D E C I L E_{i q}\right) \\
& +\mu_{i}+\mu_{t}+\varepsilon_{i q} .
\end{aligned}
$$

Depending on the specification I estimate, I include different fixed effects. To control for all unobservable firm characteristics that remain constant over time, I include firm fixed effects $\left(\mu_{i}\right)$. This is equivalent to examining the impact of delayed and immediate disseminations on the stock price reaction in a withinfirm analysis. I additionally include year, month, and day-of-the-week dummies to control for calendar effects $\left(\mu_{t}\right)$. Moreover, I use standard errors clustered at the firm level as different observations on one firm are unlikely to be independent.

Results are presented in Table 3. The coefficient on the interaction term of the delayed dissemination dummy and the earnings surprise decile is the variable of interest as it indicates the extent to which delayed disseminations affect the price reaction to different earnings surprises. If the timeliness of earnings information dissemination by data providers matters for the incorporation of information into stock prices, I expect the immediate stock price reaction to earnings news to be less sensitive for delayed disseminations by First Call and the drift to be stronger compared to immediate disseminations, that is, the coefficient on the interaction term should be negative (positive) when I focus on 2-day announcement CARs 
TABLE 3

Determinants of Announcement Returns and the Post-Earnings-Announcement Drift

Table 3 presents the results from panel regressions. The dependent variable is either the 2-day announcement cumulative abnormal return (CAR) of quarterly earnings announcements (columns 1, 3, and 5) or the 60-day post-earningsannouncement CAR (columns 2, 4, and 6). CARs are calculated as the difference between the buy-and-hold return of the respective stock and that of a size and book-to-market matching portfolio. The dummy variable DELAYED equals 1 if First Call disseminates the earnings news with a delay of at least 1 trading day (i.e., if the time lag between the activation date and the announcement date is positive), and 0 if First Call disseminates the earnings news immediately on the day of the earnings announcement (i.e., if the time lag is 0 ). Earnings announcements are sorted into SUE_DECILE every calendar quarter based on the earnings surprise. In columns 3-6, the variables EXTRA_ITEMS, SIZE_DECILE, BM_DECILE, INSTITUTIONAL, SHARE_TURNOVER, LOG_ANALYSTS, DISPERSION, EPS_VOLATILITY, EPS_PERSISTENCE, REPORTING_LAG, and ANNOUNCEMENTS_DECILE are included as controls but not reported. All controls are also interacted with the variable SUE_DECILE (not reported). Appendix C provides detailed descriptions of all control variables. Standard errors are clustered at the firm level. $t$-statistics are provided in parentheses. ${ }^{*},{ }^{* *}$, and ${ }^{* *}$ indicate significance at the $10 \%, 5 \%$, and $1 \%$ levels, respectively.

\begin{tabular}{|c|c|c|c|c|c|c|}
\hline & 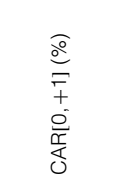 & 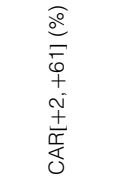 & 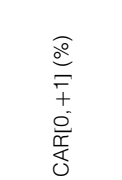 & 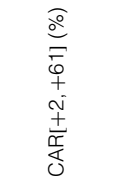 & 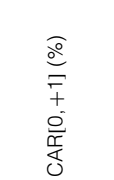 & 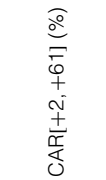 \\
\hline Independent Variable & 1 & 2 & 3 & 4 & 5 & 6 \\
\hline DELAYED & $\begin{array}{l}0.667^{\star \star *} \\
(4.27)\end{array}$ & $\begin{array}{l}-1.033^{\star *} \\
(-2.37)\end{array}$ & $\begin{array}{l}0.770^{\star \star \star} \\
(4.91)\end{array}$ & $\begin{array}{l}-1.038^{\star \star} \\
(-2.38)\end{array}$ & $\begin{array}{l}0.895^{\star \star \star} \\
(5.17)\end{array}$ & $\begin{array}{l}-0.346 \\
(-0.73)\end{array}$ \\
\hline SUE_DECILE & $\begin{array}{l}0.771^{* * *} \\
(54.46)\end{array}$ & $\begin{array}{l}0.114^{* * *} \\
(3.77)\end{array}$ & $\begin{array}{l}0.848^{\star \star \star} \\
(13.22)\end{array}$ & $\begin{array}{l}0.560^{\star \star \star} \\
(3.43)\end{array}$ & $\begin{array}{l}0.932^{\star \star \star} \\
(13.33)\end{array}$ & $\begin{array}{c}0.241 \\
(1.38)\end{array}$ \\
\hline $\begin{array}{l}\text { DELAYED } \times \\
\text { SUE_DECILE }\end{array}$ & $\begin{array}{l}-0.185^{* * *} \\
(-7.09)\end{array}$ & $\begin{array}{l}0.240^{* * *} \\
(3.48)\end{array}$ & $\begin{array}{l}-0.192^{\star \star \star} \\
(-7.39)\end{array}$ & $\begin{array}{l}0.230^{\star \star \star} \\
(3.33)\end{array}$ & $\begin{array}{l}-0.193^{\star \star \star} \\
(-6.95)\end{array}$ & $\begin{array}{l}0.147^{\star \star} \\
(1.99)\end{array}$ \\
\hline Constant & $\begin{array}{l}-3.959^{* * *} \\
(-49.82)\end{array}$ & $\begin{array}{l}-0.301^{*} \\
(-1.66)\end{array}$ & $\begin{array}{l}-3.849^{\star \star \star} \\
(-10.25)\end{array}$ & $\begin{array}{l}-5.181^{\star \star \star} \\
(-5.10)\end{array}$ & $\begin{array}{l}-2.919^{\star \star \star} \\
(-5.62)\end{array}$ & $\begin{array}{l}13.481^{\star \star \star} \\
(9.11)\end{array}$ \\
\hline $\begin{array}{l}\text { Controls } \\
\text { Firm fixed effects } \\
\text { Year fixed effects } \\
\text { Month fixed effects } \\
\text { Day-of-week fixed effects }\end{array}$ & $\begin{array}{l}\text { No } \\
\text { No } \\
\text { No } \\
\text { No } \\
\text { No }\end{array}$ & $\begin{array}{l}\text { No } \\
\text { No } \\
\text { No } \\
\text { No } \\
\text { No }\end{array}$ & $\begin{array}{l}\text { Yes } \\
\text { No } \\
\text { No } \\
\text { No } \\
\text { No }\end{array}$ & $\begin{array}{l}\text { Yes } \\
\text { No } \\
\text { No } \\
\text { No } \\
\text { No }\end{array}$ & $\begin{array}{l}\text { Yes } \\
\text { Yes } \\
\text { Yes } \\
\text { Yes } \\
\text { Yes }\end{array}$ & $\begin{array}{l}\text { Yes } \\
\text { Yes } \\
\text { Yes } \\
\text { Yes } \\
\text { Yes }\end{array}$ \\
\hline $\begin{array}{l}\text { Adj. } R^{2} \\
N\end{array}$ & $\begin{array}{r}0.076 \\
79,986\end{array}$ & $\begin{array}{r}0.001 \\
79,210\end{array}$ & $\begin{array}{r}0.087 \\
79,986\end{array}$ & $\begin{array}{r}0.005 \\
79,210\end{array}$ & $\begin{array}{r}0.112 \\
79,986\end{array}$ & $\begin{array}{r}0.051 \\
79,210\end{array}$ \\
\hline
\end{tabular}

(60-day post-earnings-announcement CARs). In column 1, when focusing on the immediate stock price response, the coefficient on the interaction term is indeed negative and statistically significant (at the $1 \%$ level), indicating that the initial stock price reaction to earnings news is less sensitive for delayed disseminations. In contrast, in column 2, looking at the delayed price response, the coefficient on the interaction term is positive and statistically significant (at the $1 \%$ level), suggesting that the post-earnings-announcement drift is stronger for delayed distributions. In columns 3 and 4, I add control variables and in columns 5 and 6 I include the full set of control variables as well as firm and calendar fixed effects. However, the results do not change materially. In the most robust specifications in columns 5 and 6, delayed disseminations are associated with a $20.7 \%$ lower immediate price response and a $61.0 \%$ stronger delayed reaction, differences that are also economically meaningful. Because the effect is robust to the inclusion of a variety of control variables and to the inclusion of different calendar fixed effects, it is not simply due to observable differences in earnings announcements, nor is the effect particular to a certain year, a certain month, or a certain day of the week. Moreover, the inclusion of firm fixed effects ensures that I estimate the effect of delayed dissemination on the market reaction to earnings news in a within-firm setting. Hence, my interpretation of these results is that the weaker initial price 
reaction and the stronger delayed reaction are because some subscribers of First Call rely on First Call to process and disseminate earnings information.

I conduct several robustness tests. First, I use propensity score matching to identify earnings announcements that are disseminated immediately but that are otherwise similar across all observable dimensions to earnings news disseminated with a delay. Thereby, I address potential concerns that there is a nonlinear factor that distinguishes delayed and immediate disseminations that is not adequately controlled for in the linear regression specifications in my main analysis (e.g., extreme earnings surprises). To do so, I run a logit regression in which the dependent variable is the dummy variable that equals 1 for earnings news disseminated with a delay, and 0 otherwise. I include all earnings, firm, and market characteristics as explanatory variables. Marginal effects from this regression are reported in column 1 of Table IA2 in the Internet Appendix. In this logit regression, most of the results from the univariate comparisons of earnings, firm, and market characteristics hold. ${ }^{14}$ I then use these estimates to generate a propensity score for each observation. Next, I employ the propensity scores to match each earnings announcement that was disseminated with a delay with an earnings announcement that was distributed immediately using the nearest-neighbor matching method with replacement. This matching results in the pairing of 14,370 delayed disseminations for which all earnings, firm, and market characteristics are available with 11,907 earnings releases that are disseminated immediately. I then rerun the logit regression from column 1 of Table IA 2 to check the significance of coefficient estimates once the matching has been performed. Results are presented in column 2 of Table IA2. In the matched sample, all coefficient estimates turn statistically insignificant, suggesting that observations are similar across observable dimensions except for the timeliness of earnings dissemination. I then replicate the analysis from Table 3 using the matched sample. Results are presented in Table IA3 in the Internet Appendix. Across all specifications, I find that the earnings response coefficient in the event window is significantly lower for delayed disseminations and the corresponding post-earnings-announcement drift is significantly higher. Hence, my results do not change materially in a matched sample.

In a further robustness test, I deviate from the convention in the literature to measure the immediate price response to earnings news over the 2-day announcement window. Instead, I define the announcement effect more strictly and focus on the reaction on the day of the earnings release. To be consistent, I then measure the post-earnings-announcement drift starting from the day after the earnings announcement date. I expect this to strengthen my results as First Call disseminates a substantial number of earnings announcements on the day after the actual earnings release, and when using the broader 2-day announcement window, the delayed price response to these delayed disseminations is in part attributed to the announcement window. I rerun the analysis from Table 3 using these alternative event and postevent windows. Table IA4 in the Internet Appendix provides the regression estimates. Consistent with expectations, this analysis yields results that

\footnotetext{
${ }^{14} \mathrm{~A}$ few of the relations change sign or significance in the multivariate setting. Earnings persistence is now positively and significantly related to delayed disseminations, and the coefficients on the bookto-market ratio, institutional ownership, and earnings volatility are no longer statistically significant.
} 
are statistically and economically stronger than the results I obtain using my baseline model.

I perform a number of additional robustness tests. Results are presented in Table IA5 in the Internet Appendix. In columns 1 and 2, I replicate the analysis from columns 5 and 6 of Table 3 but classify earnings announcements as delayed if they are disseminated with a time lag of more than 1 trading day. Thereby, I make sure that my findings are not driven by the large group of announcements that are distributed with a delay of only 1 trading day. While the coefficient estimate on the interaction term in column 1 is similar in size and statistical significance to the coefficient estimate in column 5 of Table 3, results for the postearnings-announcement drift in column 2 are substantially stronger. In columns 3 and 4 (columns 5 and 6), I reestimate the most robust specifications from Table 3 for positive (negative) earnings surprises. Delays are more prevalent among negative earnings surprises, which raises the concern that my findings are primarily driven by earnings news of firms that go through difficult times and thus are hard to process for both data providers and investors. In columns 3 and 5, I find the earnings response coefficients for delayed disseminations to be similar. Moreover, the results in columns 4 and 6 suggest that the effect of delayed disseminations on the post-earnings-announcement drift is stronger for positive earnings news than for negative news, which is inconsistent with the alternative explanation. Finally, in columns 7-10, I rerun the analysis from columns 5 and 6 of Table 3 separately for the periods from Jan. 1995 to Aug. 2009 and from Sept. 2009 to June 2011. In Sept. 2009, First Call changed its processing and dissemination practice, which substantially improved the timeliness of earnings information dissemination (Thomson Reuters/Thomson Financial (2013)). In all specifications, results are qualitatively similar to the results I obtain using my baseline model.

\section{Speed of Correction}

So far, I have treated the timeliness of earnings information dissemination as a binary variable. Next, I examine how the length of the delay affects the market's reaction to earnings news. If investors rely on the data disseminated by First Call, I expect the speed with which the initial underreaction to earnings news is corrected to depend on the length of First Call's delays. Hence, I run panel regressions with the announcement CAR computed over different horizons as the dependent variable. My main independent variables are three dummy variables that capture different magnitudes of delays, the earnings surprise decile, and interaction terms of the delayed disseminations dummies and the earnings surprise decile. In forming the three groups of delayed disseminations, I follow the categorization in Table 1 . The first delayed dissemination dummy equals 1 for earnings announcements disseminated with a delay of exactly 1 trading day, and 0 otherwise. The second and third delayed dummies capture delays of 2-5 and 6-61 trading days, respectively. Regressions contain the full set of control variables, individually and interacted with the earnings surprise decile, as well as firm and calendar fixed effects.

Results of this analysis are shown in Table 4. I predict the difference in announcement CARs between delayed and immediate disseminations to vanish following First Call's distribution of the delayed information. However, I do not 
Table 4 presents the results from panel regressions. The dependent variable is the cumulative abnormal return (CAR) of quarterly earnings announcements over various horizons. CARs are calculated as the difference between the buyand-hold return of the respective stock and that of a size and book-to-market matching portfolio. The dummy variable DELAYED ${ }_{1}$ equals 1 if First Call disseminates the earnings news with a delay of 1 trading day, and 0 otherwise. The dummy variable DELAYED $2-5$ equals 1 if First Call disseminates the earnings news with a delay of 2-5 trading days, and 0 otherwise. The dummy variable DELAYED ${ }_{6-61}$ equals 1 if First Call disseminates the earnings news with a delay of 6-61 trading days, and 0 otherwise. Earnings announcements are sorted into SUE DECILE every calendar quarter based on the earnings surprise. Each regression contains the variables DELAYED 1 , DELAYED ${ }_{2-5}$, DELAYED $6-61$, and SUE_DECILE (not reported). Moreover, the variables EXTRA_ITEMS, SIZE_DECILE, BM_DECILE, INSTITUTIONAL, SHARE TURNOVER, LOG_ANALYSTS, DISPERSION, EPS_VOLATILITY, EPS_PERSISTENCE, REPORTING_LAG, and ANNOUNCEMENTS_DECILE are included in every regression as controls but not reported. All controls are also interacted with the variable SUE DECILE (not reported). Appendix C provides detailed descriptions of all control variables. Standard errors are clustered at the firm level. $t$-statistics are provided in parentheses. ${ }^{*},{ }^{* *}$, and ${ }^{* * *}$ indicate significance at the $10 \%, 5 \%$, and $1 \%$ levels, respectively.

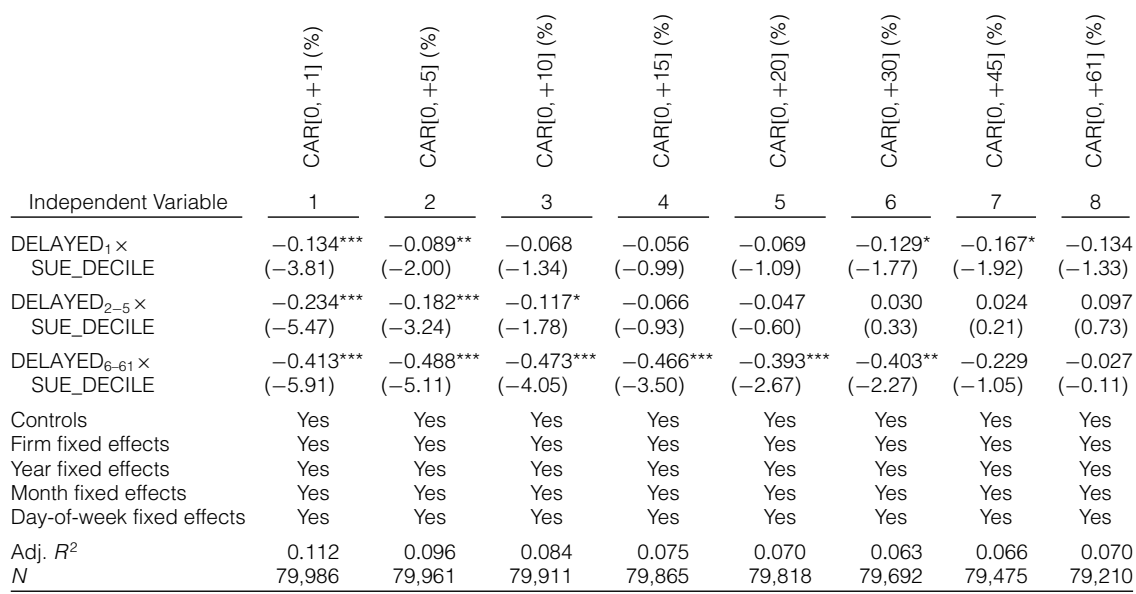

expect the gap to close immediately after the dissemination by First Call because the activation date in the First Call database is most likely a noisy proxy for the date on which First Call data are distributed to clients. Although some First Call subscribers with demand for timely data will receive the earnings information close to the activation date, other subscribers with lower demand for timely data will get it only with additional delays. Consistent with this conjecture, I find that the differential in the initial price reaction to earnings news turns insignificant in the days after the announcement if First Call disseminates the earnings news with a delay of 1 trading day. If First Call disseminates the information with a delay of 2-5 trading days, announcement CARs of delayed and immediate disseminations are only weakly statistically different in the second week after the announcement $(t$-statistic $=1.78)$ and no longer statistically different after 10 trading days. Finally, if the delay is between 6 and 61 trading days, the differential in the price reaction turns insignificant after 30 trading days.

Figure 2 graphically illustrates my results. I plot interdecile CAR spreads between the most positive earnings news (SUE_DECILE $=10$ ) and the most negative earnings news (SUE_DECILE $=1$ ) over the entire event and postevent window separately for the group of earnings news disseminated with a delay of 1 trading day, the group of news disseminated with a delay of 2-5 trading days, the group of news disseminated with a delay of 6-61 trading days, and the group of news disseminated immediately by First Call. CARs of all three groups 
FIGURE 2

Speed of Correction

Figure 2 shows average interdecile cumulative abnormal return (CAR) spreads between the decile with the most positive earnings surprises (SUE_DECILE $=10$ ) and the decile with the most negative earnings surprises (SUE_DECILE $=1$ ) over the entire event and postevent window for the group of earnings announcements disseminated by First Call with a delay of 1 trading day (DELAYED $)_{1}$ ), the group of announcements disseminated with a delay of $2-5$ trading days $\left(\right.$ DELAYED $\left._{2-5}\right)$, the group of announcements disseminated with a delay of 6-61 trading days (DELAYED $\left.6-61\right)$, and the group of announcements disseminated immediately (IMMEDIATE). CARs are calculated as the difference between the buy-and-hold return of the respective stock and that of a size and book-to-market matching portfolio.

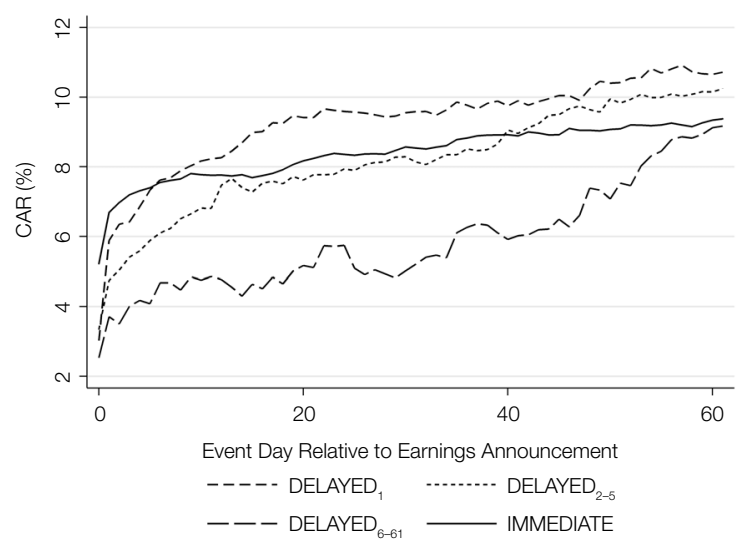

of delayed disseminations converge toward CARs of immediate disseminations. However, the larger the time lag, the longer it takes CARs of delayed disseminations to catch up with CARs of immediately distributed earnings news. Taken together, my findings provide strong evidence that the length of the delay is associated with the speed with which the underreaction to earnings news is corrected.

\section{Identification Analysis: Does the Effect Reflect an Association or Causality?}

My results so far suggest that delayed disseminations of earnings news are associated with a lower immediate and a stronger delayed price reaction compared to immediate disseminations. However, the evidence presented need not necessarily reflect a causal effect from delayed disseminations to stock prices. Two particular threats to identification exist: First, my findings might be driven by reverse causality. Up to Sept. 2009, First Call waited until the majority of analysts covering a stock had issued updated reports and only then did it adjust actuals based on this majority basis and distribute them. Therefore, the lower sensitivity of the market reaction to earnings news disseminated with a delay and the stronger drift could be due to First Call waiting for sell-side analysts to issue updated reports, and sell-side analysts may wait to publish their reports in case there is limited interest in earnings announcements. ${ }^{15}$ Second, my results might be

\footnotetext{
${ }^{15}$ In Table IA5 in the Internet Appendix, I separately run the analysis for the pre-rule-change period and the post-rule-change period. In the post-rule-change period after Sept. 2009, the reverse causality issue is resolved. However, in both subperiods, delayed disseminations are associated with a weaker immediate price response and a stronger drift. This provides the first evidence that my results are not driven by reverse causality.
} 
affected by correlated omitted variables. The processing time required by financial data providers to run validations and quality controls may coincide with the time required by investors and analysts to understand the implications of earnings releases. Thus, the weaker initial market reaction to earnings disseminated with a delay by data providers and the stronger drift might be driven by the processing time required by investors and analysts rather than by the timeliness of earnings information dissemination by data providers.

To mitigate endogeneity concerns, I examine the market's reaction on the day of the actual dissemination by First Call for earnings announcements that are disseminated with a delay. Specifically, in the post-earnings-announcement window, I compare abnormal returns around the day of the delayed dissemination with abnormal returns on nondissemination days. I expect that significantly more information is incorporated into prices when First Call distributes the delayed information than on nondissemination days. I focus on the 7,978 earnings announcements that are disseminated with a delay of at least 2 trading days. ${ }^{16}$ Moreover, to ensure that my analysis is not contaminated by analysts issuing updated reports around the day of the delayed dissemination, I exclude observations when there was a forecast issued on the respective stock in the 3-day window around the delayed dissemination. Thus, I am left with 4,324 earnings announcements disseminated with a delay by First Call. Because I control for confounding events, this analysis allows me to plausibly isolate the effect of the dissemination by First Call on the stock market reaction to earnings news.

I regress the 2-day CAR on each event day in the 60-day post-earningsannouncement window on a dummy variable that equals 1 for the day of the delayed dissemination by First Call, the earnings surprise decile, and an interaction term of the delayed dissemination day dummy and the earnings surprise decile. ${ }^{17}$ I then add event fixed effects and event-day fixed effects to the regression. Event fixed effects control for all event-specific characteristics that remain constant over the postevent window (e.g., stronger price reaction following larger surprises) and allow me to investigate the impact of the dissemination day in a within-event analysis. Thus, event fixed effects replace all standard control variables. In addition, event-day fixed effects account for all event-day-specific factors (e.g., stronger price reaction immediately after the earnings announcement). In every regression, I use standard errors adjusted for clustering by event because the observations for one specific event are not independent.

Results are presented in Table 5. If subscribers of First Call trade upon the delayed dissemination of earnings information by First Call, I expect the coefficient on the interaction term of the dummy variable for the day of the delayed dissemination and the earnings surprise variable to have a positive sign. My results are in line with this conjecture. In column 1, I find the coefficient to be positive and highly statistically significant $(t$-statistic $=3.39)$. In terms of economic magnitude, the coefficient estimate on the interaction term is roughly half the size of the coefficient estimate on the interaction term in column 6 of Table 3 ,

\footnotetext{
${ }^{16}$ I obtain similar results if I include the observations disseminated with a delay of 1 trading day.

${ }^{17} \mathrm{My}$ findings are qualitatively similar if I use daily abnormal returns rather than 2-day CARs as the dependent variable.
} 
TABLE 5

Abnormal Returns around the Day of the Delayed Dissemination

Table 5 presents the results from panel regressions. The dependent variable is the 2-day cumulative abnormal return (CAR) on each event day over the entire post-earnings-announcement window. The sample is restricted to earnings announcements that are disseminated with a delay of at least 2 trading days. Moreover, I exclude earnings announcements when there was a forecast issued on the respective stock in the 3-day window around the delayed dissemination by First Call. CARs are calculated as the difference between the buy-and-hold return of the respective stock and that of a size and book-to-market matching portfolio. The dummy variable DAY_OF_DELAYED_DISSEMINATION equals 1 on the day of the delayed dissemination by First Call, and 0 otherwise. Earnings announcements are sorted into SUE_DECILE every calendar quarter based on the earnings surprise. Standard errors are clustered at the event level. $t$-statistics are provided in parentheses. ${ }^{* \star}$ and ${ }^{* *}$ indicate significance at the $5 \%$ and $1 \%$ levels, respectively.

\begin{tabular}{|c|c|c|}
\hline \multirow[b]{2}{*}{ Independent Variable } & \multicolumn{2}{|c|}{ CAR $[+2,+3] \ldots$ CAR $[+61,+62](\%)$} \\
\hline & 1 & 2 \\
\hline DAY_OF_DELAYED_DISSEMINATION & $\begin{array}{l}-0.362^{* * *} \\
(-2.90)\end{array}$ & $\begin{array}{l}-0.313^{\star \star} \\
(-2.45)\end{array}$ \\
\hline SUE_DECILE & $\begin{array}{l}0.020^{* * *} \\
(5.58)\end{array}$ & \\
\hline $\begin{array}{l}\text { DAY_OF_DELAYED_DISSEMINATION x } \\
\text { SUE_DECILE }\end{array}$ & $\begin{array}{l}0.070^{* * *} \\
(3.39)\end{array}$ & $\begin{array}{l}0.059^{\star \star \star} \\
(2.77)\end{array}$ \\
\hline Constant & $\begin{array}{l}-0.116^{* * *} \\
(-5.34)\end{array}$ & $\begin{array}{l}0.023 \\
(0.41)\end{array}$ \\
\hline $\begin{array}{l}\text { Event fixed effects } \\
\text { Event-day fixed effects }\end{array}$ & $\begin{array}{l}\text { No } \\
\text { No }\end{array}$ & $\begin{array}{l}\text { Yes } \\
\text { Yes }\end{array}$ \\
\hline $\begin{array}{l}\text { Adj. } R^{2} \\
N\end{array}$ & $\begin{array}{r}0.000 \\
255,599\end{array}$ & $\begin{array}{r}0.013 \\
255,599\end{array}$ \\
\hline
\end{tabular}

suggesting that the abnormal price reaction on the day of the delayed dissemination and the day after can explain approximately $50 \%$ of the difference in drifts between delayed and immediate distributions. In column 2, I add event fixed effects and event-day fixed effects to the specification from column 1. The coefficient on the interaction term remains both economically and statistically significant. The significant abnormal price reaction upon delayed disseminations by First Call poses a particular challenge to non-data-provider explanations and affirms that investors indeed trade on the information disseminated by major financial data providers.

Figure 3 graphically illustrates my findings. In Graph A, I plot abnormal return spreads between the most positive earnings surprises (SUE_DECILE $=8$, SUE_DECILE $=9$, or SUE_DECILE $=10$ ) and the most negative earnings surprises (SUE_DECILE $=1$, SUE_DECILE $=2$, or SUE_DECILE $=3$ ) around the day of the delayed dissemination. I again focus on the 60-day post-earningsannouncement window. Hence, this analysis neither includes the earnings announcement day nor the day after the earnings announcement. Day $t=0$ is the day on which First Call activates the delayed earnings information in its system. I document a peak in abnormal returns on the day of the delayed dissemination and the day after. In Graph B, I demean abnormal returns by event and by event day (relative to the earnings announcement date). The effect of demeaning is comparable to the effect of including event fixed effects and event-day fixed effects in a regression. I find that the return spread fluctuates around 0 before the delayed dissemination and turns positive and significant on the day of the delayed dissemination and the day after, providing evidence that investors trade in the direction of the earnings surprise upon release of the information in the First Call system. 
FIGURE 3

\section{Abnormal Returns around the Day of the Delayed Dissemination}

Figure 3 shows average (demeaned) abnormal return spreads between the most positive earnings surprises $\left(\mathrm{SUE} \_D E C I L E=8\right.$, SUE_DECILE $=9$, or SUE_DECILE = 10) and the most negative earnings surprises (SUE_DECILE $=1$, SUE_DECILE $=2$, or SUE_DECILE $=3$ ) around the day of the delayed dissemination by First Call in Graph A (Graph B). I focus on the 60-day post-earnings-announcement window. Thus, this analysis does not include the earnings announcement date. The sample is restricted to earnings announcements that are disseminated with a delay of at least 2 trading days. Moreover, I exclude earnings announcements when there was a forecast issued on the respective stock in the 3-day window around the delayed dissemination by First Call. Day $t=0$ is the day of the delayed dissemination. Abnormal returns are calculated as the difference between the raw return of the respective stock and that of a size and book-to-market matching portfolio. I show point estimates together with 95\% confidence intervals. In Graph B, abnormal returns are demeaned by event and by event day (relative to the earnings announcement date).
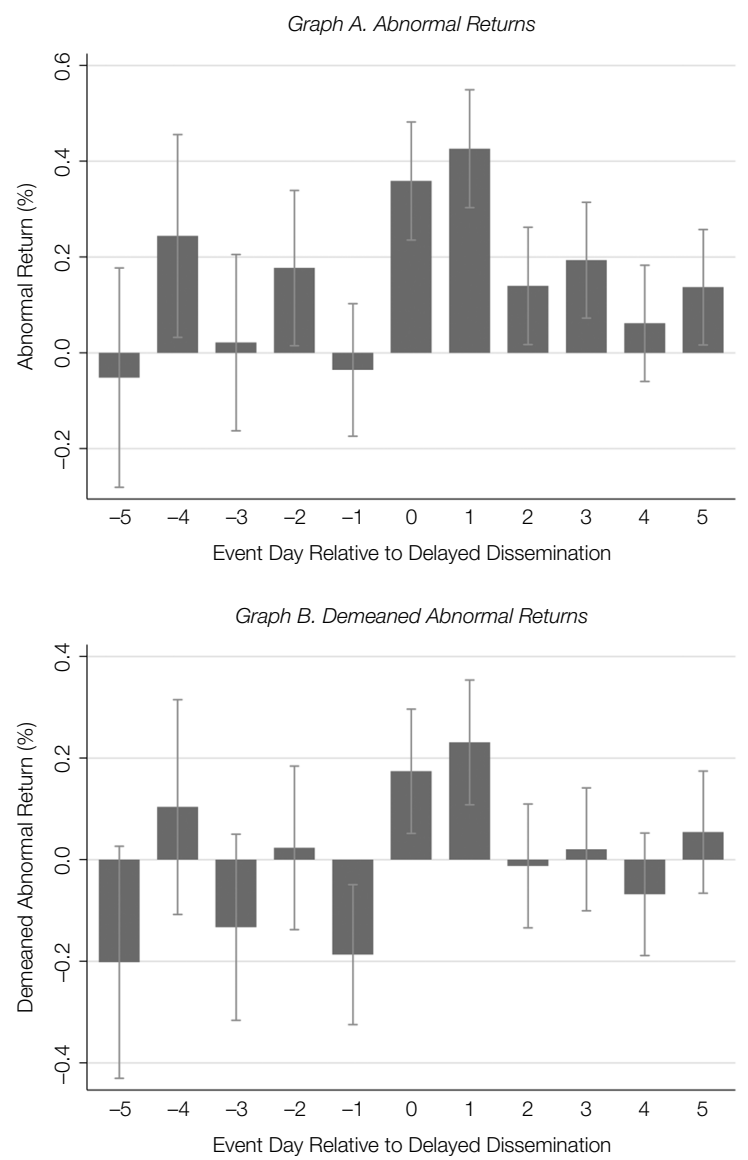

\section{Additional Analyses}

\section{A. Effect of Delayed Disseminations on Trading Activity}

Next, I investigate trading activity around earnings announcements. If my results are indeed driven by subscribers of First Call not knowing about certain announcements or not having the relevant information to trade upon them, I expect 
a similar attenuation of the trading volume as I observe for stock prices around earnings releases. To examine whether the timeliness of earnings information dissemination also matters for trading activity, I compare the announcement trading volume reaction of earnings news disseminated with a delay and earnings news disseminated immediately.

I follow previous research and define the abnormal announcement trading volume as the average daily log dollar trading volume during the event window minus the average daily log dollar trading volume during the pre-event window, where the event window is the 2-day window around the earnings release and the pre-event window is the 30-day window that ends 10 days before the announcement date (e.g., DellaVigna and Pollet (2009), Hirshleifer et al. (2009), and Chi and Shanthikumar (2017)). The trading volume data come from CRSP:

$$
\begin{aligned}
{\text { ABNORMAL_VOLUME }[0,+1]_{i q}=} & \frac{1}{2} \sum_{t=0}^{t=1} \log \left(1+\operatorname{VOLUME}_{i t}\right) \\
& -\frac{1}{30} \sum_{t=-40}^{t=-11} \log \left(1+\operatorname{VOLUME}_{i t}\right),
\end{aligned}
$$

where $\operatorname{VOLUME}_{i t}$ is the dollar trading volume of firm $i$ on day $t$. Firm $i$ announces its earnings for quarter $q$ on day $t=0$. I winsorize the abnormal volume at the $1 \%$ and $99 \%$ levels to eliminate outliers.

I run panel regressions with the 2-day average abnormal announcement trading volume as the dependent variable. A dummy variable that equals 1 if First Call disseminates the earnings news with a delay and all earnings, firm, and market characteristics are used as independent variables. I include the market abnormal volume as an additional control (e.g., Hirshleifer et al. (2009), Chi and Shanthikumar (2017)). Depending on the estimated specification, I include firm, year, month, and day-of-the-week fixed effects.

I show the results of the different estimations in Table 6. The coefficient of interest is the coefficient on the delayed dissemination dummy. I expect the abnormal trading volume on the day of the earnings announcement to be lower if First Call does not immediately disseminate earnings information, that is, the coefficient on the delayed dissemination dummy is expected to have a negative sign. Column 1 provides results for the regression using the delayed dissemination dummy as the only independent variable. In column 2, I add control variables and in column 3 I include the full set of control variables as well as firm and calendar fixed effects. The coefficient on the delayed dissemination dummy is always negative and statistically significant at the $1 \%$ level. The announcement effect is between $10.5 \%$ and $11.9 \%$ weaker for delayed disseminations compared to the 2-day average abnormal volume of immediate distributions. My results are consistent with fewer investors knowing about the earnings announcement or having the relevant earnings data to trade upon it if First Call does not process and disseminate earnings information on the day of the announcement.

Next, I replicate my identification analysis from the previous section using the abnormal volume rather than abnormal returns. Figure 4 graphically illustrates 


\begin{tabular}{|c|c|c|c|}
\hline \multirow[b]{2}{*}{ Independent Variable } & \multicolumn{3}{|c|}{ ABNORMAL_VOLUME $[0,+1]$} \\
\hline & 1 & 2 & 3 \\
\hline DELAYED & $\begin{array}{l}-0.064^{\star \star *} \\
(-8.41)\end{array}$ & $\begin{array}{l}-0.072^{\star \star \star} \\
(-10.02)\end{array}$ & $\begin{array}{l}-0.070^{\star \star \star} \\
(-9.86)\end{array}$ \\
\hline Constant & $\begin{array}{c}0.607^{\star * *} \\
(119.56)\end{array}$ & $\begin{array}{c}0.427^{\text {}} \\
(19.35)\end{array}$ & $\begin{array}{l}0.563^{\star \star \star} \\
(14.16)\end{array}$ \\
\hline $\begin{array}{l}\text { Controls } \\
\text { Firm fixed effects } \\
\text { Year fixed effects } \\
\text { Month fixed effects } \\
\text { Day-of-week fixed effects }\end{array}$ & $\begin{array}{l}\text { No } \\
\text { No } \\
\text { No } \\
\text { No } \\
\text { No }\end{array}$ & $\begin{array}{l}\text { Yes } \\
\text { No } \\
\text { No } \\
\text { No } \\
\text { No }\end{array}$ & $\begin{array}{l}\text { Yes } \\
\text { Yes } \\
\text { Yes } \\
\text { Yes } \\
\text { Yes }\end{array}$ \\
\hline $\begin{array}{l}\text { Adj. } R^{2} \\
N\end{array}$ & $\begin{array}{r}0.001 \\
79,986\end{array}$ & $\begin{array}{r}0.096 \\
79,986\end{array}$ & $\begin{array}{r}0.225 \\
79,986\end{array}$ \\
\hline
\end{tabular}

my findings. In Graph A, I plot the abnormal volume around the day of the delayed dissemination by First Call. I document a peak in trading activity when First Call activates the delayed information in its system on day $t=0$. This effect is significantly different from trading activity on nondissemination days in the post-earnings-announcement window, indicating that the trading volume reaction to earnings news is at least partially shifted from the announcement date to First Call's delayed dissemination date. In Graph B, I demean the abnormal volume by event and by event day, thereby accounting for event-specific and event-dayspecific effects. I find that the demeaned abnormal trading volume is negative on the days before First Call's delayed dissemination and becomes positive on the day of the delayed dissemination and the 2 days after. Again, alternative non-dataprovider explanations have a considerably harder time explaining the significant abnormal trading activity I observe around First Call's delayed disseminations.

\section{B. Effect of Delayed Disseminations on Liquidity}

In this section, I investigate whether data providers also matter for stock market liquidity. Many studies show that public disclosures reduce information asymmetry (e.g., Diamond and Verrecchia (1991), Healy, Hutton, and Palepu (1999), and Leuz and Verrecchia (2000)). However, to the extent that the information provided in the disclosures is ambiguous or the disclosures are not disseminated to a broader set of market participants, information asymmetry may still prevail. Hence, if First Call does not immediately determine and disseminate an earnings surprise, this likely results in greater information asymmetry compared to earnings releases that First Call processes and distributes on the day of the earnings announcement. I use bid-ask spreads and depths as proxies for information 


\section{FIGURE 4}

\section{Abnormal Trading Volume around the Day of the Delayed Dissemination}

Figure 4 shows the average (demeaned) abnormal trading volume around the day of the delayed dissemination by First Call in Graph A (Graph B). I focus on the 60-day post-earnings-announcement window. Thus, this analysis does not include the earnings announcement date. The sample is restricted to earnings announcements that are disseminated with a delay of at least 2 trading days. Moreover, I exclude earnings announcements when there was a forecast issued on the respective stock in the 3-day window around the delayed dissemination by First Call. Day $t=0$ is the day of the delayed dissemination. The abnormal volume is calculated as the event-day log dollar trading volume minus the preperiod average daily log dollar trading volume, where the pre-period is the 30 trading days that end 10 days before the earnings announcement date. I show point estimates together with 95\% confidence intervals. In Graph B, the abnormal volume is demeaned by event and by event day (relative to the earnings announcement date).
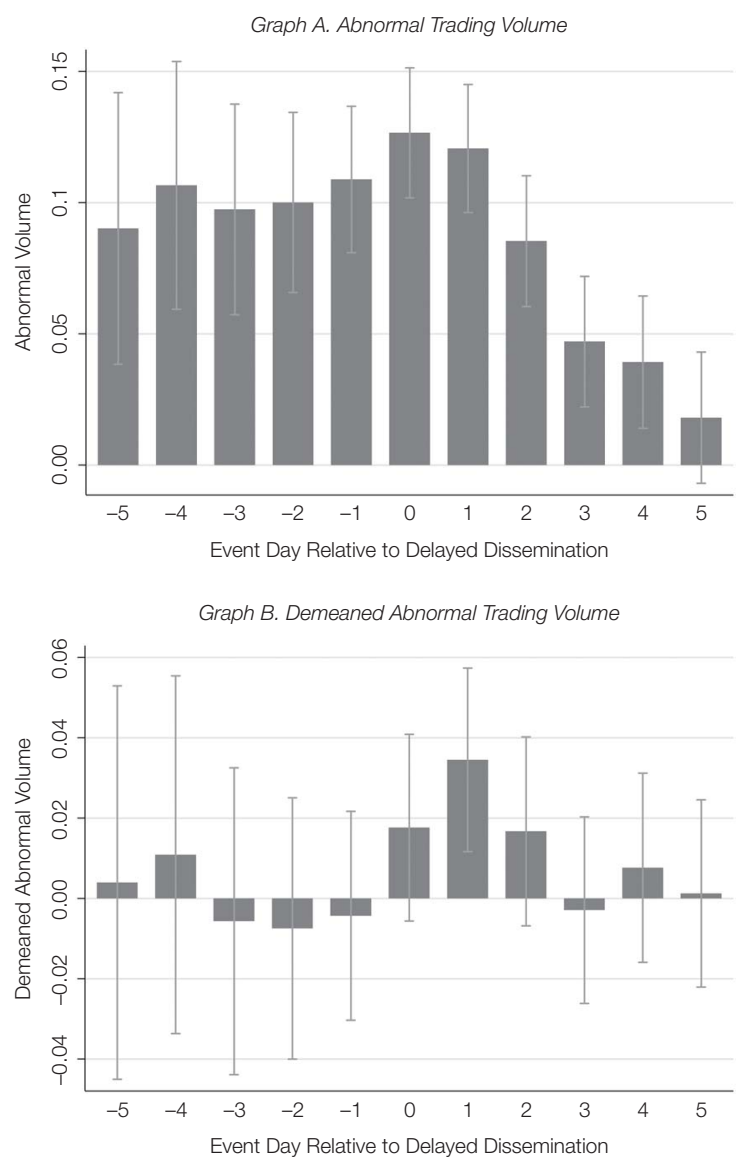

asymmetry and compare them for the group of earnings announcements disseminated with a delay and the group of announcements disseminated immediately. ${ }^{18}$

\footnotetext{
${ }^{18}$ Inventory risk might be an alternative and complementary channel through which delayed disseminations affect liquidity. So and Wang (2014) provide evidence that market makers adjust liquidity provision based on the anticipated level of uncertainty associated with information events to compensate themselves for varying levels of inventory risk. If delayed disseminations by First Call tend to be information events that are perceived as more uncertain by market makers, market makers likely demand higher compensation for inventory risk on days with delayed disseminations.
} 
I follow previous studies in computing abnormal bid-ask spreads and abnormal depths (e.g., Bushee et al. (2010), Blankespoor et al. (2014)). Using Trade and Quote (TAQ) data, I define abnormal bid-ask spreads as the event-period average daily spread minus the pre-period average daily spread, where the event period is the 3-day window around the earnings release and the pre-period is the 60 trading days before the event period. The daily spread is the daily average of each quote's spread, calculated as the difference between the offer price and the bid price divided by the midpoint of the offer price and the bid price. I focus on quotes with a positive spread and remove quotes with a spread greater than $90 \%$. I measure abnormal depths as the average daily log depth during the event window minus the average daily log depth during the pre-event period. The daily depth is the daily average of each quote's depth, calculated as the sum of the dollar offer size and the dollar bid size. Depths are computed with the same quotes used to compute spreads:

$$
\begin{aligned}
\text { ABNORMAL_SPREAD }[-1,+1]_{i q}= & \frac{1}{3} \sum_{t=-1}^{t=1} \operatorname{SPREAD}_{i t}-\frac{1}{60} \sum_{t=-61}^{t=-2} \operatorname{SPREAD}_{i t}, \\
\text { ABNORMAL_DEPTH }[-1,+1]_{i q}= & \frac{1}{3} \sum_{t=-1}^{t=1} \log \left(1+\mathrm{DEPTH}_{i t}\right) \\
& -\frac{1}{60} \sum_{t=-61}^{t=-2} \log \left(1+\mathrm{DEPTH}_{i t}\right),
\end{aligned}
$$

where $\operatorname{SPREAD}_{i t}$ is the average daily bid-ask spread of firm $i$ on day $t$ and $\mathrm{DEPTH}_{i t}$ is the average daily depth of firm $i$ on day $t$. Firm $i$ announces its earnings for quarter $q$ on day $t=0$. I winsorize abnormal spreads and abnormal depths at the $1 \%$ and $99 \%$ levels.

I examine the relation between data providers' information dissemination and market liquidity by estimating regressions of abnormal bid-ask spreads and abnormal depths on the delayed dissemination dummy variable. I include all control variables from previous analyses. In addition, following the extensive literature on the determinants of market liquidity, I add the abnormal trading volume during the event window, prior-quarter stock return volatility, and the stock price at the end of the most recent calendar quarter as additional controls (e.g., Leuz and Verrecchia (2000), Bushee et al. (2010), and Soltes (2010)). Depending on the specification I estimate, I also include firm and calendar fixed effects.

Table 7 provides the coefficient estimates for these regressions. In columns $1-3$, I use the abnormal bid-ask spread as the dependent variable and in columns 4-6 abnormal depth. In columns 1 and 4, the delayed dissemination dummy is the only explanatory variable. In columns 2 and 5, I add all controls and in columns 3 and 6 regressions additionally contain firm and time fixed effects. If delayed disseminations result in greater information asymmetry (or increased inventory risk) compared to immediate disseminations, I expect larger spreads and lower depths in the case of delayed information dissemination. Consistent with expectations, when the abnormal spread is the dependent variable, the coefficient estimate on the delayed dummy variable is positive and statistically significant across 
TABLE 7

Determinants of Abnormal Announcement Bid-Ask Spreads and Depths

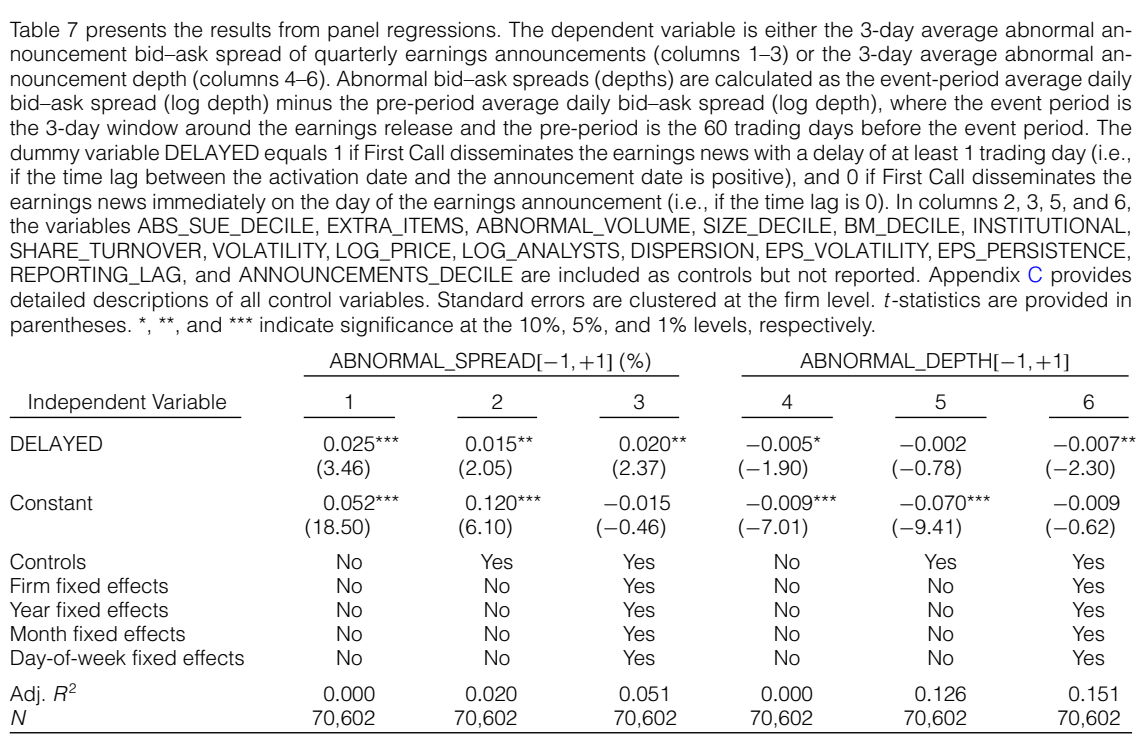

all specifications. In columns 4-6, when the abnormal depth is the dependent variable, the coefficient estimate on the delayed dummy is always negative and statistically significant in two of three specifications. Overall, my results suggest that delayed disseminations of earnings news by data providers are indeed associated with reduced market liquidity, suggesting that data providers are also relevant for market makers and other liquidity suppliers when setting spreads and depths.

\section{Is the Effect also Observable for Other Data Providers?}

To corroborate my findings from the First Call database, I also run my analysis with quarterly earnings announcements as reported by IBES. Thomson Reuters acquired not only First Call in the early 2000s but also IBES. IBES started to store two different dates for the announcement date and the activation date of earnings announcements in 2001. Thus, my IBES sample begins in Jan. 2002. Although the First Call database for academic research was discontinued in June 2011, IBES data are still available today. Nevertheless, to ensure comparability with First Call results, my sample period ends in June 2011. After applying the same set of filters to my IBES data as I do to the First Call data, I am left with 94,069 observations in the IBES sample. Table IA1 in the Internet Appendix describes the sample selection process. To ensure that my analysis of IBES data is not driven by the same observations available in First Call, I merge the two databases and keep only observations that are unique to the IBES sample. This results in a final sample of 30,761 earnings announcements.

Table IA6 in the Internet Appendix provides descriptive statistics on the IBES sample. From 2002 to 2011, 63.4\% of earnings news are classified as immediately disseminated and the remaining $36.6 \%$ are classified as delayed. The distribution is similar in the sample containing all observations. In the First Call 
sample, focusing on the same period, $80.5 \%$ of earnings are disseminated immediately and only $19.5 \%$ are distributed with a delay. Thus, timeliness of information dissemination seems to be a bigger issue in the IBES database than in First Call. However, the yearly pattern of time lags is comparable to the pattern discovered in Table 1. After Sept. 2009, the fraction of delayed dissemination decreases substantially to approximately $10 \%$.

In Table IA7, I rerun the analysis from Table 3 using IBES data. Regression specifications are identical to the specifications in Table 3. However, the documented effects for delayed disseminations are both economically and statistically weaker compared to my findings for First Call. In unreported tests, I reestimate all specifications using the entire IBES sample rather than just observations unique to the IBES databases. However, this yields inferences that are qualitatively similar. In contrast, when I use First Call data and investigate the period from 2002 to 2011, I find the initial price reaction to be significantly weaker and the drift to be significantly stronger for delayed disseminations (not reported). This suggests that IBES plays a minor role in disseminating earnings information in capital markets. However, in Table IA8, I replicate the analysis using a narrower announcement window and a broader postannouncement window (this analysis is similar to the analysis in Table IA4). With these alternative event and postevent windows, I find significant results in five of six specifications, indicating that the distribution of information by IBES also impacts investor trading.

I also rerun my causality test using IBES data. Results of this analysis are graphically illustrated in Figure IA1. I plot abnormal return spreads between the most positive earnings surprises (SUE_DECILE $=8$, SUE_DECILE $=9$, or SUE_DECILE $=10$ ) and the most negative earnings surprises (SUE_DECILE $=1$, SUE_DECILE $=2$, or SUE_DECILE = 3) around the day of the delayed dissemination by IBES. Consistent with my findings for First Call, I document a significant abnormal return effect on the day of the delayed dissemination and the day after.

\section{Is the Effect Also Observable for Other Data?}

Finally, I investigate whether the timeliness of information dissemination matters not only for earnings announcements but also for sell-side analyst recommendations. First Call distributes earnings information as well as analyst recommendations. In fact, most brokerage firms rely on First Call to send their research reports electronically to their institutional clients (Green (2006)). Hence, I expect the timeliness of information dissemination by First Call to also affect the market reaction to analyst recommendations. In the case of recommendations, delays occur mainly because brokers submit research reports with a delay to First Call. First Call does not adjust analyst recommendations, and thus any effect documented for data providers in this setting is likely to be a pure rebroadcasting effect.

I again focus on the period from Jan. 1995 to June 2011. I restrict my sample to recommendation upgrades and downgrades. An analyst recommendation is characterized as an upgrade (e.g., from buy to strong buy) or downgrade (e.g., from buy to hold) by comparing the stock's current recommendation with its previous recommendation. My final sample consists of 96,024 upgrades and 119,566 downgrades. 
Table IA9 in the Internet Appendix reports descriptive statistics on analyst recommendations. Approximately $21.4 \%$ of analyst recommendations are disseminated with a delay over the entire sample period. While First Call improved the timeliness of information dissemination in the case of earnings, the fraction of analyst recommendations disseminated with a delay steadily increased over previous years, most likely driven by brokers increasingly submitting research reports with a delay. In 2011, approximately half of all recommendations were not immediately distributed on the day of publication.

To analyze the relation between the timeliness of information dissemination and the market's reaction to analyst recommendations, I regress the 2-day announcement CARs of analyst recommendations and the 20-day postannouncement CARs on a dummy variable for delayed disseminations. I limit the drift analysis to the 20-day postannouncement window because previous research shows that the postrecommendation drift is short-lived and mainly observed over roughly a 1-month period after the publication (e.g., Stickel (1995), Womack (1996), and Barber, Lehavy, McNichols, and Trueman (2001)). The most robust specification contains firm-broker fixed effects. In such a specification, I essentially compare the stock price reaction to analyst recommendations disseminated with a delay and those disseminated immediately within each firm-broker pair. In addition, I account for calendar effects by including year, month, and day-of-the-week fixed effects.

Results are reported in Table 8. I run regressions separately for upgrades (columns 1-4) and downgrades (columns 5-8). When focusing on announcement CARs, I find that the initial price reaction to recommendations disseminated with a delay is significantly weaker compared to immediate disseminations. When the postrecommendation drift is the dependent variable, the regression specifications in columns 2, 6, and 8 do not yield significant results. However, in the within-firm analysis in column 4, I document a significantly stronger drift for recommendation upgrades distributed with a delay.

In Figure 5, I replicate my identification test from Figure 3 for analyst recommendations. I conduct the test separately for upgrades (Graph A) and downgrades (Graph B). In Graph A of Figure 5, I find that the abnormal return on the day of the delayed dissemination and the day after is significantly different from 0 . Similarly, in Graph B, I document a negative and significant dissemination effect for recommendation downgrades, even though downgrades disseminated with a delay are not associated with a stronger drift in Table 8. Taken together, the results in this section provide evidence that First Call also plays an important role in facilitating investor access to sell-side research.

\section{Conclusion}

This study investigates whether large financial data providers such as First Call (Thomson Reuters) serve as important information intermediaries in capital markets. First Call collects earnings information from multiple sources and distributes it to a very broad investor base. By validating and adjusting earnings information, First Call also creates new content. Through these activities, First 


\section{FIGURE 5}

\section{Abnormal Returns around the Day of the Delayed Dissemination of Analyst Recommendations}

Figure 5 shows average abnormal returns around the day of the delayed dissemination of analyst recommendations by First Call. I focus on the 20-day post-recommendation-announcement window. Thus, this analysis does not include the recommendation announcement date. The sample is restricted to recommendation upgrades (Graph A) and downgrades (Graph B) that are disseminated with a delay of at least 2 trading days. I characterize an analyst recommendation as an upgrade (e.g., from buy to strong buy) or downgrade (e.g., from buy to hold) by comparing the stock's current with its previous recommendation. Day $t=0$ is the day of the delayed dissemination. Abnormal returns are calculated as the difference between the raw return of the respective stock and that of a size and book-to-market matching portfolio. I show point estimates together with $95 \%$ confidence intervals.
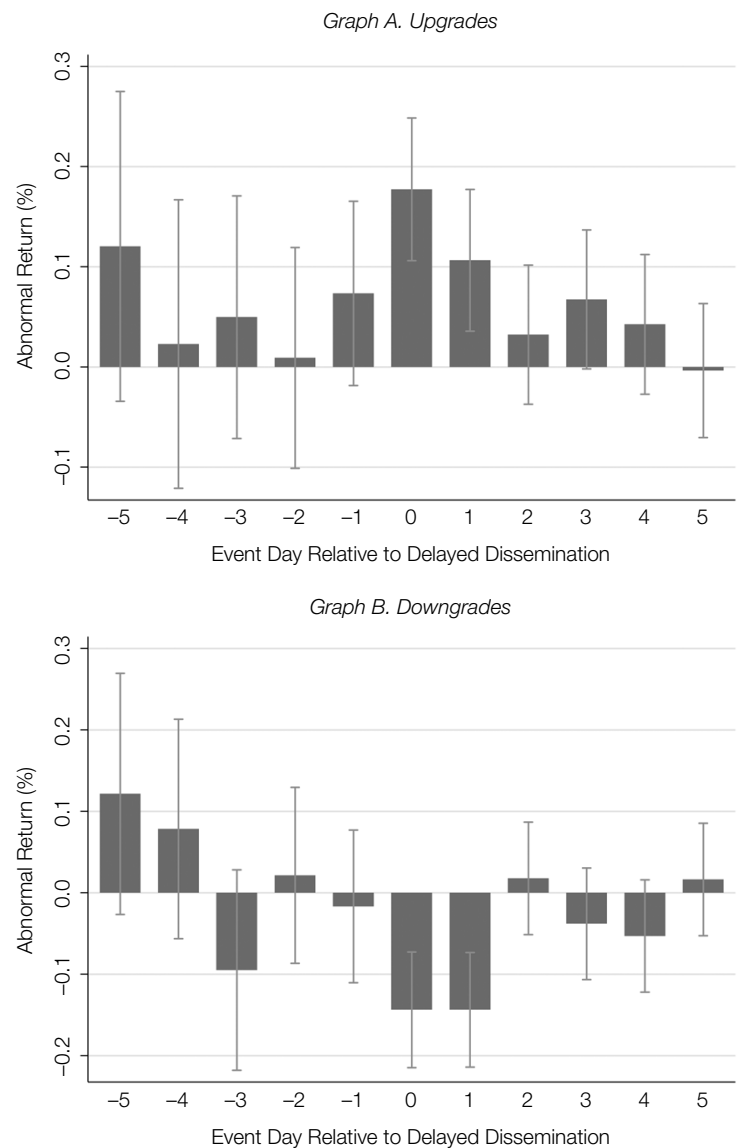

Call has the potential to affect the information environment in capital markets and the trading behavior of investors.

I find that the immediate price and volume reaction to a firm's earnings surprise is weaker and the post-earnings-announcement drift stronger when First Call distributes earnings information with a delay. To mitigate endogeneity concerns, I study the market reaction on the day of the delayed dissemination and document that a significant part of the stronger drift following earnings announcements disseminated with a delay is clustered around this day. In further tests, I show that First Call data are also relevant for market makers when setting spreads 


\section{TABLE 8}

\section{Determinants of Announcement Returns and the Postannouncement Drift} of Analyst Recommendations

Table 8 presents the results from panel regressions. The dependent variable is either the 2-day announcement cumulative abnormal return (CAR) of analyst recommendation revisions (columns 1, 3,5, and 7) or the 20-day postannouncement CAR (columns 2, 4, 6, and 8). I restrict the sample to recommendation upgrades (columns 1-4) and downgrades (columns 5-8). I characterize an analyst recommendation as an upgrade (e.g., from buy to strong buy) or downgrade (e.g., from buy to hold) by comparing the stock's current with its previous recommendation. CARs are calculated as the difference between the buy-and-hold return of the respective stock and that of a size and book-to-market matching portfolio. The dummy variable DELAYED equals 1 if First Call disseminates the analyst recommendation with a delay of at least 1 trading day (i.e., if the time lag between the activation date and the announcement date is positive), and 0 if First Call disseminates the analyst recommendation immediately on the day of the earnings announcement (i.e., if the time lag is 0 ). Appendix C provides detailed descriptions of all control variables. Standard errors are clustered at the firm level. $t$-statistics are provided in parentheses. ${ }^{*},{ }^{\star *}$, and ${ }^{* * *}$ indicate significance at the $10 \%, 5 \%$, and $1 \%$ levels, respectively.

\begin{tabular}{|c|c|c|c|c|c|c|c|c|}
\hline & \multicolumn{4}{|c|}{ Upgrades } & \multicolumn{4}{|c|}{ Downgrades } \\
\hline & 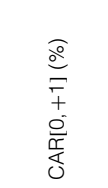 & 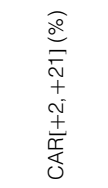 & 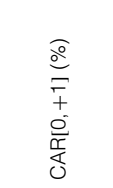 & 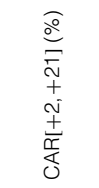 & 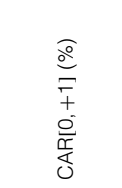 & 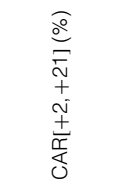 & $\begin{array}{l}\widehat{o} \\
\stackrel{o}{\sigma} \\
\bar{t} \\
\frac{0}{0} \\
\frac{\pi}{0} \\
0\end{array}$ & 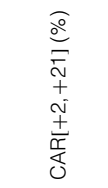 \\
\hline Independent Variable & 1 & 2 & 3 & 4 & 5 & 6 & 7 & 8 \\
\hline DELAYED & $\begin{array}{l}-0.260^{* * *} \\
(-4.64)\end{array}$ & $\begin{array}{l}-0.010 \\
(-0.11)\end{array}$ & $\begin{array}{l}-0.497^{\text {** }} \\
(-4.98)\end{array}$ & $\begin{array}{l}0.257^{\text {** }} \\
(2.47)\end{array}$ & $\begin{array}{l}0.783^{\text {*** }} \\
(9.42)\end{array}$ & $\begin{array}{r}0.120 \\
(1.22)\end{array}$ & 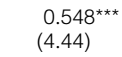 & $\begin{array}{c}0.086 \\
(0.84)\end{array}$ \\
\hline Constant & $\begin{array}{l}2.451^{\text {** }} \\
(70.24)\end{array}$ & $\begin{array}{l}0.743^{\star \star \star} \\
(15.06)\end{array}$ & $\begin{array}{l}2.127^{\star \star \star} \\
(9.29)\end{array}$ & $\begin{array}{l}0.733^{\star \star \star} \\
(2.74)\end{array}$ & $\begin{array}{l}-3.604^{\star * \star} \\
(-64.88)\end{array}$ & $\begin{array}{l}-0.336^{\star \star \star} \\
(-5.83)\end{array}$ & 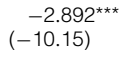 & $\begin{array}{l}-0.948^{\star \star \star} \\
(-3.86)\end{array}$ \\
\hline $\begin{array}{l}\text { Firm-broker fixed effects } \\
\text { Year fixed effects } \\
\text { Month fixed effects } \\
\text { Day-of-week fixed effects }\end{array}$ & $\begin{array}{l}\text { No } \\
\text { No } \\
\text { No } \\
\text { No }\end{array}$ & $\begin{array}{l}\text { No } \\
\text { No } \\
\text { No } \\
\text { No }\end{array}$ & $\begin{array}{l}\text { Yes } \\
\text { Yes } \\
\text { Yes } \\
\text { Yes }\end{array}$ & $\begin{array}{l}\text { Yes } \\
\text { Yes } \\
\text { Yes } \\
\text { Yes }\end{array}$ & $\begin{array}{l}\text { No } \\
\text { No } \\
\text { No } \\
\text { No }\end{array}$ & $\begin{array}{l}\text { No } \\
\text { No } \\
\text { No } \\
\text { No }\end{array}$ & $\begin{array}{l}\text { Yes } \\
\text { Yes } \\
\text { Yes } \\
\text { Yes }\end{array}$ & $\begin{array}{l}\text { Yes } \\
\text { Yes } \\
\text { Yes } \\
\text { Yes }\end{array}$ \\
\hline $\begin{array}{l}\text { Adj. } R^{2} \\
N\end{array}$ & $\begin{array}{r}0.000 \\
96,024\end{array}$ & $\begin{array}{r}-0.000 \\
95,788\end{array}$ & $\begin{array}{r}0.097 \\
96,024\end{array}$ & $\begin{array}{r}0.040 \\
95,788\end{array}$ & $\begin{array}{r}0.001 \\
119,566\end{array}$ & $\begin{array}{r}0.000 \\
118,779\end{array}$ & $\begin{array}{r}0.165 \\
119,566\end{array}$ & $\begin{array}{r}0.058 \\
118,779\end{array}$ \\
\hline
\end{tabular}

and depths. In addition, results are similar when I run the analysis with earnings data from another data provider and with sell-side analyst recommendations. Thus, these findings suggest that large financial data suppliers do indeed fulfill a role as important information intermediaries in capital markets.

\section{Appendix A. Earnings Information on Thomson ONE}

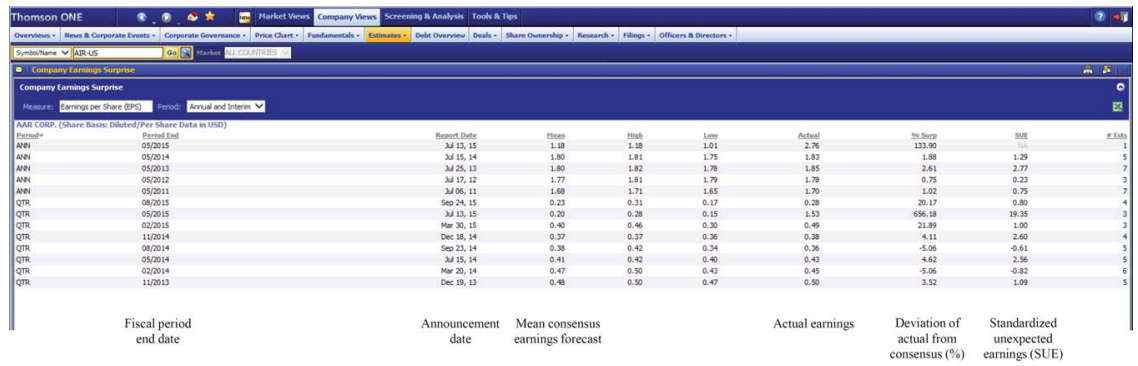




\section{Appendix B. Sample Earnings Announcement}

On Wednesday, Mar. 12, 2008, after the close of the market, Susser Holdings Corporation, an operator of convenience stores and fuel distributor, reports fourth-quarter earnings of US\$7.54 million or US\$0.44 per share. This includes a nonrecurring tax benefit of US\$6.6 million or US\$0.39 per share. The median estimate of the six analysts that cover the company is US $\$ 0.09$ per share for the fourth quarter. One analyst (Sidoti) issues updated forecasts on the next day and two analysts (Morgan and Merrill Lynch) update their forecasts on Friday, Mar. 14. Thereafter, there are no new analyst reports until mid-April. First Call's validations and quality checks take another 2 trading days. First Call disseminates adjusted earnings of US $\$ 0.05$ per share on Tuesday, Mar. 18. Together with adjusted earnings, First Call distributes a footnote in which it states that it excludes the nonrecurring tax benefit.

Figure B1 shows abnormal returns around the announcement date of Susser Holdings Corporation's fourth-quarter earnings. As the earnings announcement takes place outside of trading hours, I allocate it to Thursday, Mar. 13. The abnormal return is close to 0 on Mar. 12, the day before the announcement. It is negative on the day of the announcement and the day after. On Monday, Mar. 17, the abnormal return becomes positive. However, abnormal returns again turn negative on the day of the delayed dissemination by First Call and the day after.

FIGURE B1

Abnormal Returns around the Announcement Date of Susser Holdings Corporation's Fourth-Quarter Earnings

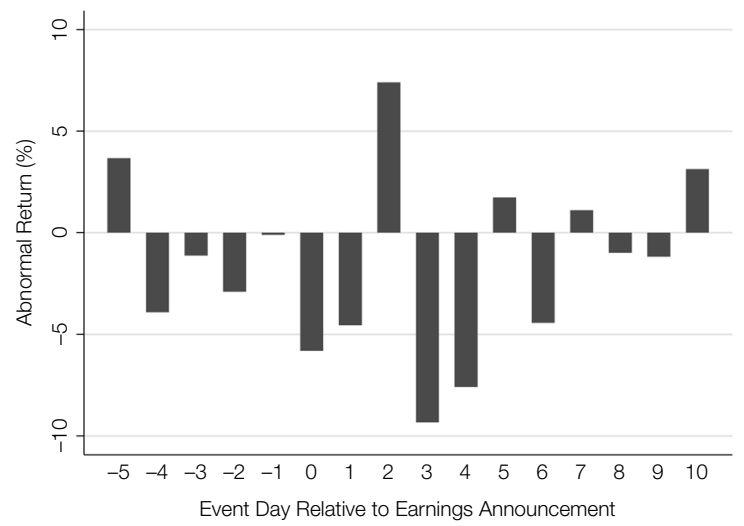

\section{Appendix C. Variable Descriptions}

SUE: $\operatorname{SUE}_{i q}=\left(A_{i q}-F_{i q}\right) / P_{i q}$, where $A_{i q}$ is the announced earnings of firm $i$ for quarter $q$, $F_{i q}$ is the most recent median consensus forecast for firm $i$ and quarter $q$, and $P_{i q}$ is the stock price of firm $i$ at the end of the most recent calendar quarter. Source: First Call, CRSP.

SUE_DECILE: Every calendar quarter, I sort stocks into deciles based on their earnings surprise. Source: First Call, CRSP.

ABS_SUE: |SUE|. Source: First Call, CRSP. 
ABS_SUE_DECILE: Every calendar quarter, I sort stocks into deciles based on the absolute value of their earnings surprise. Source: First Call, CRSP.

EXTRA_ITEMS: Dummy variable that equals 1 for earnings announcements with nonzero extraordinary items and discontinued operations, and 0 otherwise. Source: Compustat.

MARKET_CAP: Share price $\times$ Number of shares outstanding (in million); calculated at the end of June of each year. Source: CRSP.

SIZE_DECILE: Every calendar quarter, I sort stocks into deciles based on their market capitalization; I use size breakpoints as provided by Kenneth French on his Web site. Source: CRSP.

BM: Book value of equity for the last fiscal year-end in the previous calendar year / Market capitalization at the end of December of the previous calendar year; calculated at the end of June of each year; winsorized at the 99\% level. Source: Compustat, CRSP.

BM_DECILE: Every calendar quarter, I sort stocks into deciles based on their book-tomarket ratio; I use book-to-market ratio breakpoints as provided by Kenneth French on his Web site. Source: Compustat, CRSP.

INSTITUTIONAL: Shares held by institutional investors / Number of shares outstanding; calculated at the end of the most recent calendar quarter; winsorized to $100 \%$. Source: Thomson Reuters Institutional Holdings (13F), CRSP.

SHARE_TURNOVER: Average monthly share trading volume over a 1-year period / Average number of shares outstanding over a 1-year period; calculated at the end of the most recent calendar quarter; winsorized at the $99 \%$ level. Source: CRSP.

ANALYSTS: Number of analysts that form the most recent consensus forecast; calculated on the earnings announcement date. Source: First Call.

LOG_ANALYSTS: $\log$ (Number of analysts). Source: First Call.

DISPERSION: Standard deviation of earnings forecasts that form the most recent consensus forecast / |Mean consensus forecast|; calculated on the earnings announcement date; winsorized at the $99 \%$ level. Source: First Call.

EPS_VOLATILITY: Standard deviation of the deviations of quarterly earnings from the previous year's quarterly earnings over the past 4 years; calculated on the earnings announcement date; at least 4 observations required; winsorized at the $99 \%$ level. Source: First Call.

EPS_PERSISTENCE: First-order autocorrelation coefficient of quarterly earnings over the past 4 years; calculated on the earnings announcement date; at least 4 observations required. Source: First Call.

REPORTING_LAG: Earnings announcement date - End of corresponding fiscal quarter; calculated on the earnings announcement date; winsorized at the $99 \%$ level. Source: First Call.

ANNOUNCEMENTS: Number of earnings announcements per day; calculated on the earnings announcement date. Source: First Call.

ANNOUNCEMENTS_DECILE: Every calendar quarter, I sort stocks into deciles based on the number of earnings announcements on their earnings announcement date. Source: First Call.

MARKET_VOLUME: Average abnormal trading volume across all firms during the earnings announcement window. Source: CRSP. 
VOLATILITY: Stock return volatility in the prior quarter; calculated at the end of the most recent calendar quarter. Source: CRSP.

PRICE: Stock price at the end of the most recent calendar quarter. Source: CRSP.

LOG_PRICE: $\log$ (Stock price). Source: CRSP.

\section{References}

Ball, R., and P. Brown. "An Empirical Evaluation of Accounting Income Numbers." Journal of Accounting Research, 6 (1968), 159-178.

Barber, B.; R. Lehavy; M. McNichols; and B. Trueman. "Can Investors Profit from the Prophets? Security Analyst Recommendations and Stock Returns.” Journal of Finance, 56 (2001), 531-563.

Bernard, V., and J. Thomas. "Post-Earnings Announcement Drift: Delayed Price Response or Risk Premium?" Journal of Accounting Research, 27 (1989), 1-48.

Blankespoor, E.; G. Miller; and H. White. "The Role of Dissemination in Market Liquidity: Evidence from Firms' Use of Twitter.” Accounting Review, 89 (2014), 79-112.

Brennan, M. J.; N. Jegadeesh; and B. Swaminathan. "Investment Analysis and the Adjustment of Stock Prices to Common Information.” Review of Financial Studies, 6 (1993), 799-824.

Brennan, M. J., and A. Subrahmanyam. "Investment Analysis and Price Formation in Securities Markets.” Journal of Financial Economics, 38 (1995), 361-381.

Bushee, B.; J. Core; W. Guay; and S. Hamm. "The Role of the Business Press as an Information Intermediary." Journal of Accounting Research, 48 (2010), 1-19.

Chi, S. S., and D. M. Shanthikumar. "Local Bias in Google Search and the Market Response around Earnings Announcements." Accounting Review, 92 (2017), 115-143.

deHaan, E.; T. Shevlin; and J. Thornock. "Market (In)Attention and the Strategic Scheduling and Timing of Earnings Announcements.” Journal of Accounting and Economics, 60 (2015), 36-55.

DellaVigna, S., and J. Pollet. "Investor Attention and Friday Earnings Announcements." Journal of Finance, 64 (2009), 709-749.

Diamond, D. W., and R. E. Verrecchia. "Disclosure, Liquidity and the Cost of Capital." Journal of Finance, 46 (1991), 1325-1359.

D’Souza, J. M.; K. Ramesh; and M. Shen. “The Interdependence between Institutional Ownership and Information Dissemination by Data Aggregators." Accounting Review, 85 (2010), 159-193.

El-Gazzar, S. M. "Predisclosure Information and Institutional Ownership: A Cross-Sectional Examination of Market Revaluations during Earnings Announcement Periods." Accounting Review, 73 (1998), 119-129.

Engelberg, J., and C. Parsons. "The Causal Impact of Media in Financial Markets." Journal of Finance, 66 (2011), 67-97.

Frederickson, J. R., and L. Zolotoy. "Competing Earnings Announcements: Which Announcement Do Investors Process First?” Accounting Review, 91 (2016), 441-462.

Green, T. C. "The Value of Client Access to Analyst Recommendations." Journal of Financial and Quantitative Analysis, 41 (2006), 1-24.

Healy, P.; A. Hutton; and K. Palepu. "Stock Performance and Intermediation Changes Surrounding Sustained Increases in Disclosure." Contemporary Accounting Research, 16 (1999), 485-520.

Hirshleifer, D.; S. S. Lim; and S. H. Teoh. "Driven to Distraction: Extraneous Events and Underreaction to Earnings News.” Journal of Finance, 5 (2009), 2289-2325.

Hou, K.; L. Peng; and W. Xiong. "A Tale of Two Anomalies: The Implications of Investor Attention for Price and Earnings Momentum.” Working Paper, Ohio State University (2009).

Huberman, G., and T. Regev. "Contagious Speculation and a Cure for Cancer." Journal of Finance, 56 (2001), 387-396.

Leuz, C., and R. E. Verrecchia. "The Economic Consequences of Increased Disclosure." Journal of Accounting Research, 38 (2000), 91-124.

Li, E.; K. Ramesh; and M. Shen. "The Role of Newswires in Screening and Disseminating ValueRelevant Information in Periodic SEC Reports.” Accounting Review, 86 (2011), 669-701.

Peress, J. "The Media and the Diffusion of Information in Financial Markets: Evidence from Newspaper Strikes.” Journal of Finance, 69 (2014), 2007-2043.

Piotroski, J. D., and D. T. Roulstone. "The Influence of Analysts, Institutional Investors, and Insiders on the Incorporation of Market, Industry, and Firm-Specific Information into Stock Prices." Accounting Review, 79 (2004), 1119-1151.

Rogers, J. L.; D. J. Skinner; and S. L. C. Zechman. "The Role of the Media in Disseminating InsiderTrading News." Review of Accounting Studies, 21 (2016), 711-739. 
So, E. C., and S. Wang. "News-Driven Return Reversals: Liquidity Provision Ahead of Earnings Announcements." Journal of Financial Economics, 114 (2014), 20-35.

Soltes, E. "Disseminating Firm Disclosures.” Working Paper, Harvard Business School (2010).

Stickel, S. E. "The Anatomy of the Performance of Buy and Sell Recommendations." Financial Analysts Journal, 51 (1995), 25-39.

Thomson Reuters/Thomson Financial. "Comments Regarding Commission File Nos. SR-NASD2002-21 and SR-NYSE-2002-09." Available at http://www.sec.gov/rules/sro/nd200221ny200209/ edick1.htm (2002).

Thomson Reuters/Thomson Financial. "Thomson Financial Glossary: A Guide to Understanding Terms and Conventions for the First Call and I/B/E/S Estimates Databases" (2006).

Thomson Reuters/Thomson Financial. "I/B/E/S Estimates: Make Informed Predictions on Company Performance" (2008).

Thomson Reuters/Thomson Financial. "Methodology for Estimates: A Guide to Understanding Thomson Reuters Methodologies, Terms and Policies for I/B/E/S Estimates Databases" (2013).

Twedt, B. "Spreading the Word: Price Discovery and Newswire Dissemination of Management Earnings Guidance.” Accounting Review, 91 (2016), 317-346.

Womack, K. L. “Do Brokerage Analysts' Recommendations Have Investment Value?" Journal of Finance, 51 (1996), 137-167. 